\title{
30. CRETACEOUS FORAMINIFERAL BIO-ISOTOPE STRATIGRAPHY OF HOLE 967E AND PALEOGENE PLANKTONIC FORAMINIFERAL BIOSTRATIGRAPHY OF HOLE 966F, EASTERN MEDITERRANEAN ${ }^{1}$
}

\author{
Isabella Premoli Silva, ${ }^{2}$ Silvia Spezzaferri, ${ }^{3}$ and Antonio D'Angelantonio ${ }^{2}$
}

\begin{abstract}
During Ocean Drilling Program Leg 160, pelagic middle Eocene sediments were recovered from Hole 966F. Cretaceous and pelagic lower Oligocene sediments were recovered from Hole 967E. Both sites are located on the Eratosthenes Seamount, on the top and lower slope, respectively. The Cretaceous succession consists of pelagic sediments that overlie carbonate platform sediments. The deposition of carbonate platform sediments occurred in a shallow-water, lagoonal environment and ended in the late Aptian. Cretaceous pelagic sedimentation may have started in the Cenomanian(?) and continued up through the Maastrichtian. Despite poor recovery, a hiatus spanning the middle to late Helvetoglobotruncana helvetica Zone and the Marginotruncana sigali Zone is probably present in the Turonian, as inferred by the estimated very low sedimentation rates, and another hiatus is hypothesized between shallow-water carbonates and the overlying pelagic sequence, probably spanning the entire Albian and part of the Cenomanian. Another major hiatus was detected in Hole 967E where lower Oligocene sediments rest on upper Maastrichtian deposits. The planktonic assemblages reworked within the lower Oligocene sediments, however, indicate that sedimentation was originally more continuous on the seamount, and that several intervals were removed by downslope transport. Stable isotope stratigraphy (oxygen and carbon) tentatively allows comparison of the Cretaceous isotope record of Hole 967E with continuous and well-dated land sections in central Italy.
\end{abstract}

\section{INTRODUCTION}

Drilling on the Eratosthenes Seamount during Ocean Drilling Program (ODP) Leg 160 provided the first record of pre-Miocene pelagic and shallow-water sediments from the Eastern Mediterranean since the first Deep Sea Drilling Project cruise (Leg 13) in 1970. PreMiocene sediments were recovered in two holes from the top of the seamount (Hole 966F) and the lower slope (Hole 967E), along a transect drilled across the Eratosthenes Seamount to the Cyprus margin (Fig. 1). In Hole 966F a relatively undisturbed and clean pelagic chalk of middle Eocene age was recovered. Hole 967E penetrated deeper into the seamount, recovering a very mixed Paleogene pelagic sequence and a 400-m-thick chalk unit of Late Cretaceous age resting on a shallow-water carbonate platform belonging to the upper part of the seamount (Emeis, Robertson, Richter, et al., 1996).

This paper documents the planktonic foraminiferal distribution within the pelagic units from both Holes $966 \mathrm{~F}$ and $967 \mathrm{E}$ and the distribution of shallow-water organisms and facies from the carbonate platform unit of Hole 967E.

\section{MATERIALS AND METHODS}

Sample spacing was guided by the preliminary biostratigraphic investigations, core recovery, and lithology. It resulted in a variable sample density for the different intervals. Samples were taken at every change in lithology in the lower cores with very poor recovery. In the overlying chalk unit, samples were taken on the average of every 50 to $100 \mathrm{~cm}$. Micropaleontological studies were performed in thin section from the harder lithotypes in Cores 160-967E-50R up to 29R. From Core 160-967E-30R up to Core 160-967E-8R softer lithotypes

${ }^{1}$ Robertson, A.H.F., Emeis, K.-C., Richter, C., and Camerlenghi, A. (Eds.), 1998. Proc. ODP, Sci. Results, 160: College Station, TX (Ocean Drilling Program).

${ }^{2}$ Dipartimento di Scienze della Terra, Universitá di Milano, Via Mangiagalli 34, 20133, Milano, Italy. micro@imiucca.csi.unimi.it

${ }^{3}$ ETH-Zentrum, Geologisches Institut, Sonneggstrasse 5, 8092, Zurich, Switzerland. allowed disaggregation. Samples of about 5 to $10 \mathrm{~cm}^{3}$ were soaked in distilled water and washed under running water through 40-150 $\mu \mathrm{m}$, $150-250 \mu \mathrm{m}$, and $>250 \mu \mathrm{m}$ sieves. The three size fractions obtained were then dried at room temperature.

Abundance of single foraminiferal species and groups and other organic and inorganic components relative to the total biogenic content were estimated for both thin sections and washed residues. Five categories were distinguished and plotted in the range charts as follows $($ Tables $1-3)$ : VR $=$ very rare $(1-2$ specimens $) ; \mathrm{R}=$ rare $(2-5$ specimens); $\mathrm{F}=$ few $(5-10) ; \mathrm{C}=$ common (10-30 specimens); $\mathrm{A}=$ abundant $(>50 \%$ of the total fauna and/or biogenic content); $\mathrm{AA}=$ very abundant; $\mathrm{AAA}=$ extremely abundant (dominant).

Presence of organic and inorganic components is indicated as follows: $\mathrm{sp}=$ spicules; $\mathrm{ph}=$ phosphatic remains; fish $=$ fish teeth; $\mathrm{og}=$ organic matter; $\mathrm{I}=$ inoceramids; $\mathrm{E}=$ echinoderms; $\mathrm{O}=$ ostracods; $\mathrm{qtz}$ = quartz; $\mathrm{ox}=$ oxide $; \mathrm{gl}=$ glauconite $; \mathrm{v}=$ volcanics $; \mathrm{ch}=$ chert $;$ red $=$ brilliant red grains of unknown origin.

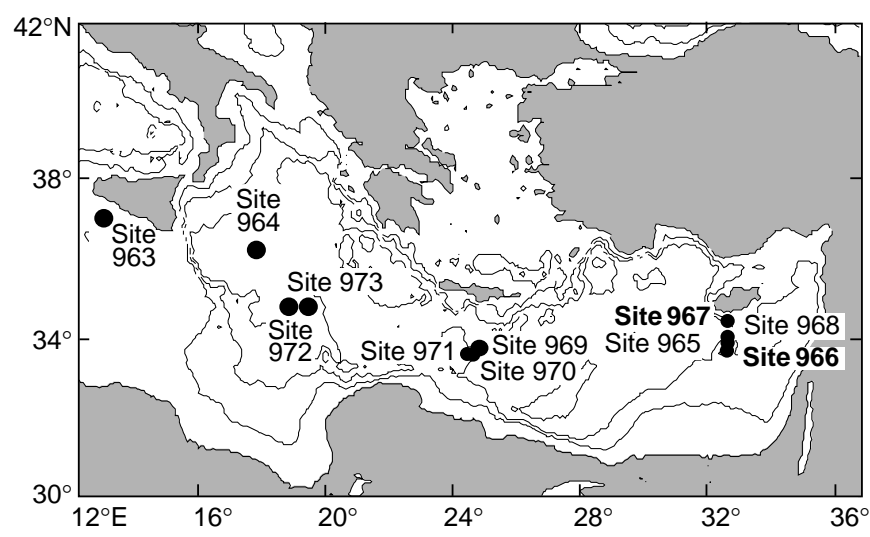

Figure 1. Location map of Sites 963 through 973, drilled during Leg 160. Sites 966 and 967 (this study) are shown in bold (after Emeis, Robertson, Richter, et al., 1996). 
Oxygen and carbon isotopes were measured on 67 bulk sediment samples, using a PRISM mass spectrometer at the ETH-Zurich. The isotope data, corrected following the procedure of Craig (1957) modified for a triple collector and relative to the international Peedee belemnite (PDB) standard, are given in Table 5.

\section{BIOSTRATIGRAPHY}

The age determinations of the Cretaceous and Paleogene pelagic sequences encountered in this study are based on planktonic foraminiferal zonal schemes proposed by Robaszynski et al. (1990, 1993), Premoli Silva and Sliter (1994), Robaszynski and Caron (1995), and Erba et al. (1995) for the Cretaceous, and Blow $(1969,1979)$ for the Paleogene.

Generic attribution and identification of planktonic foraminiferal zones follow Robaszynski et al. (1979, 1984, 1990, 1993), Caron (1985), Nederbragt (1990), Premoli Silva and Sliter (1994) for the Cretaceous taxa; Boersma and Premoli Silva (1983), Toumarkine and Luterbacher (1985), Boersma et al. (1987), Premoli Silva and Boersma (1988, 1989), Hemleben et al. (1991), Olsson et al. (1992), and Spezzaferri (1994) for the Paleogene taxa. In addition, De Castro (1966), Fourcade (1980), and Arnaud Vanneau and Premoli Silva (1995) were considered for identifying and interpreting shallowwater facies and larger foraminifers from Unit IV. Some Cretaceous planktonic and shallow-water taxa are illustrated in Plates 1 through 4.

\section{Hole 966F}

Hole $966 \mathrm{~F}$ is located on the northern edge of the plateau area of the Eratosthenes Seamount $\left(33^{\circ} 47.858^{\prime} \mathrm{N}, 32^{\circ} 42.093^{\prime} \mathrm{E}\right.$, water depth $922.9 \mathrm{~m}$, penetration $356 \mathrm{~m}$ ). The hole was drilled to $59 \mathrm{~m}$. Rotary Core Barrel (RCB) Cores 160-966F-1R through 31R were taken from 0 to $356 \mathrm{mbsf}$, with $297 \mathrm{~m}$ cored and $65.85 \mathrm{~m}$ recovered (recovery rate $22.1 \%$ ). Eocene sediments were encountered at about $300 \mathrm{mbsf}$ (Section 160-966F-26R-1), below a shallow-water carbonate sequence attributed to the Miocene, based on the presence of large benthic foraminiferal assemblages (Emeis, Robertson, Richter, et al., 1996). These rich assemblages contain numerous lepidocyclinids and miogypsinids. Their poor preservation and cuts, however, prevented identification at species level and resulted in a less precise age attribution.

The Eocene planktonic foraminiferal assemblages from Hole $966 \mathrm{~F}$ are moderately abundant and generally poorly preserved (Table 1). They consist of planktonic assemblages typical of middle Eocene Zones P10-P12, which include Acarinina bullbrooki, A. pentacamerata, A. matthewsae, A. pseudotopilensis, A. rugosoaculeata, Globanomalina pseudoscitula, Igorina broedermanni, Turborotalia pomeroli, T. griffinae, T. praecentralis, and T. pseudomayeri. Minor components include Turborotalia cerroazulensis, T. pseudoampliapertura, Subbotina praeturritilina, Dentoglobigerina galavisi, Zeaglobigerina ampliapertura, Morozovella aragonensis, M. lehneri, and the Subbotina angiporoides group.

Reworking of older specimens ranges from very rare to rare/common. It consists of rare specimens of early to mid-Paleocene and early Eocene species such as Praemurica uncinata, Morozovella conicotruncata, M. gracilis, M. subbotinae, and Acarinina nitida. In Sample $160-966 \mathrm{~F}-28 \mathrm{R}-3,74-76 \mathrm{~cm}$, reworking consists of only a few Cretaceous forms such as hedbergellids and Pseudotextularia sp.

\section{Hole 967E}

Hole $967 \mathrm{E}$ is located on the lower northern slope of the Eratosthenes Seamount $\left(34^{\circ} 04.106^{\prime} \mathrm{N}, 32^{\circ} 43.525^{\prime} \mathrm{E}\right.$, water depth 3164.3 m, penetration 600.3 m) (Emeis, Robertson, Richter, et al., 1996). The hole was drilled to 109.5 mbsf. RCB Cores 160-967E-1R through 51R were taken from 109.5 to 600.3 mbsf, with $598.35 \mathrm{~m}$ cored and $72.3 \mathrm{~m}$ recovered (recovery rate $14.8 \%$ ). Paleogene sediments were encountered between 130 and 177 mbsf; they overlie a pelagic Cretaceous sedimentary sequence that extends down to 430 mbsf (Figs. 2, 3). The sediments below the pelagic interval down to a total depth of $600.3 \mathrm{~m}$ consist of shallow-water carbonates deposited in a lagoonal environment.

\section{Shallow-Water Carbonate Facies}

Several samples were studied in thin section from Core 160967E-50R to 34R (Table 2). This succession spans the interval from the upper part of the carbonate platform through the base of the pelagic sequence.

The shallow-water facies of Unit IV overall contain very poor assemblages, mainly indicating deposition in the inner part of a restricted lagoon that rarely experienced good communication with the open ocean (Arnaud Vanneau and Premoli Silva, 1995). As shown in Table 2, ostracods and Istriloculina are the only biogenic components in most facies dominated by micrite due to bacterial activity and/or pellets. Scattered richer assemblages contain miliolids, nezzazzatids, and, rarely, small agglutinated foraminifers. Calcareous algae were rarely recorded.

Few age-diagnostic larger foraminifers, mainly Archaealveolina reicheli, were encountered in Cores 160-967E-41R, 37R, and 35R. A few specimens of $A$. reicheli were found associated with Cuneolina sp. in the latter core (160-967E-35R). According to De Castro (1966) and Fourcade (1980), A. reicheli is stratigraphically confined to the upper Aptian. A fragment of a cuneolinid was also found in Core 160-967E-34R associated with the oldest, long-ranging, planktonic foraminifers recorded from Hole 967E. According to the lithologic description (Emeis, Robertson, Richter, et al., 1996), the samples studied from Cores 160-967E-35R and 34R are resedimented calcarenites interbedded within nannofossil chalk. Thus, the presence of A. reicheli in Core 160-967E-35R suggests that the shallow-water carbonate deposition ended in the late Aptian.

\section{Cretaceous Planktonic Foraminifers}

Planktonic foraminiferal assemblages from pelagic Unit III, overlying the shallow-water carbonates, are unevenly distributed throughout (Tables 2,3). Size-sorting is very clearly shown by the variable abundance of large-sized planktonic species $(>250 \mu \mathrm{m})$ and benthic foraminifers. As a result of sorting, zonal markers are rare throughout. Fine fractions $(<150 \mu \mathrm{m})$ are dominated by fragmented larger sized or juvenile planktonic specimens, small-sized plankton, and small, mostly broken benthic foraminifers. Reworking is evident only in the lower part of the unit. These features imply that sedimentation occurred under a rather high energy environment.

In the lower part of the unit (Cores 160-967E-33R through 31R), planktonic assemblages are dominated by calcispheres and pithonellids (Table 2); their abundance dilutes the planktonic foraminifers to the point that age-diagnostic species are rare and poorly recognizable. In particular, the age of Cores 160-967E-35R through 32R could not be specified with certainty (Fig. 2). Two specimens of a possible Rotalipora were found in Samples 160-967E-33R-1, 7-10 $\mathrm{cm}$, and 160-967E-32R-1, 56-60 cm, associated with a few fragments of double keeled taxa and a few specimens of Favusella washitensis, respectively.

The double keeled fragments in Sample 160-967E-33R-1, 7-10 $\mathrm{cm}$, although not positively identified, may belong to either the dicarinellids or marginotruncanids. Given the first case (dicarinellids), the age of both samples (160-967E-33R-1, 7-10 cm, and 32R-1, 56-60 $\mathrm{cm}$ ) would be "mid" to late Cenomanian based on the distribution of $F$. washitensis. Conversely, if the double keeled specimens represent marginotruncanids, both samples cannot be older than the middle part of the Helvetoglobotruncana helvetica Zone of Turonian age, 
Table 1. Distribution of middle Eocene planktonic foraminifers in Hole 966F.

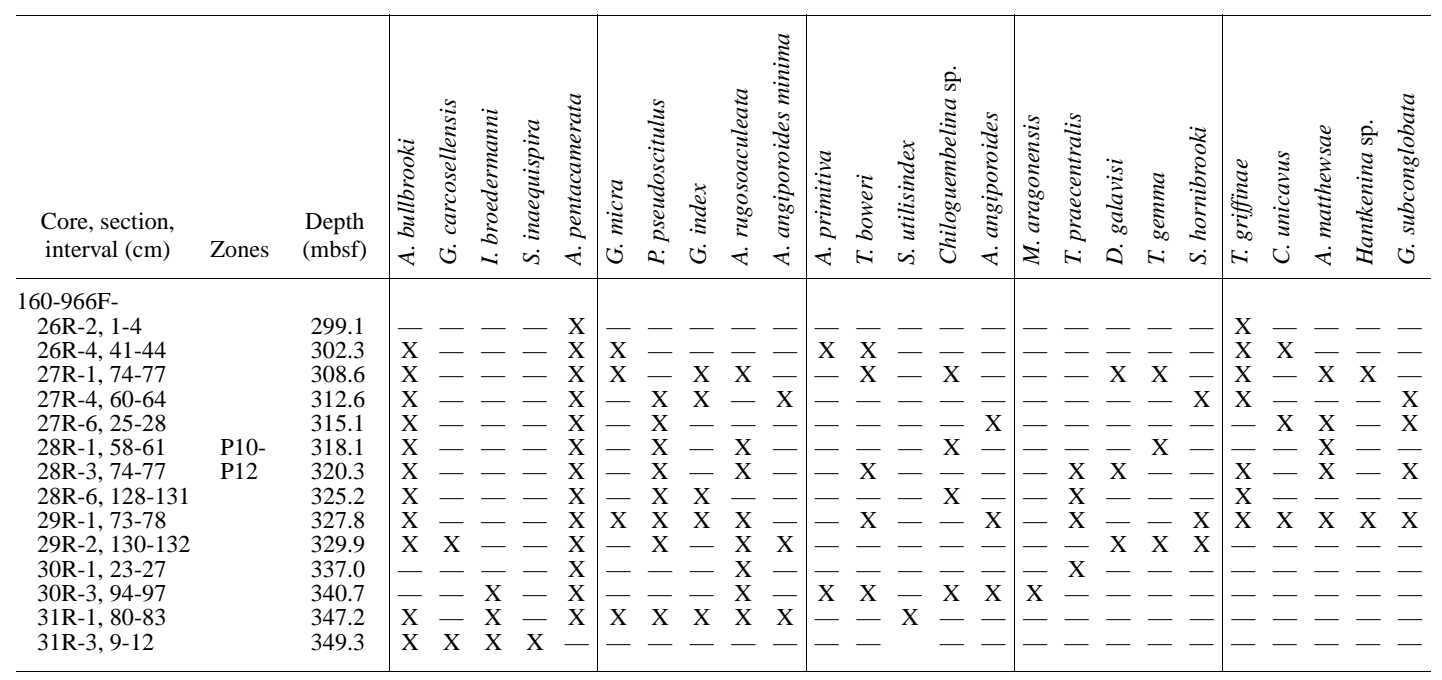

Notes: $\mathrm{X}=$ present; $\mathrm{VR}=$ very rare (1-2 specimens); $\mathrm{R}=$ rare (2-5 specimens); $\mathrm{C}=$ common (10-30 specimens).

Table 1 (continued).

\begin{tabular}{|c|c|c|c|c|c|c|c|c|c|c|c|c|c|c|c|c|c|c|}
\hline $\begin{array}{l}\text { Core, section, } \\
\text { interval }(\mathrm{cm})\end{array}$ & Zones & $\begin{array}{l}\text { Depth } \\
\text { (mbsf) }\end{array}$ & 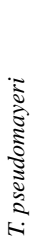 & 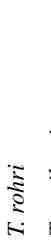 & 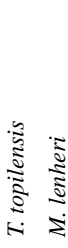 & 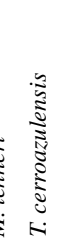 & 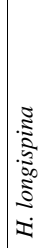 & 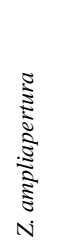 & 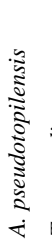 & 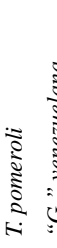 & 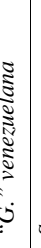 & 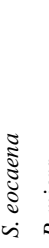 & م: & 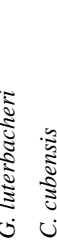 & 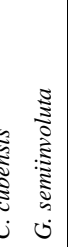 & 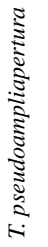 & 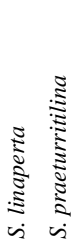 & 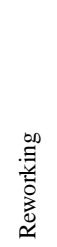 \\
\hline $160-9$ & & & & & & & & & & & & & & & & & & \\
\hline $\begin{array}{l}26 \mathrm{R}-2,1-4 \\
26 \mathrm{R}-4,41-44\end{array}$ & & $\begin{array}{l}299.1 \\
302.3\end{array}$ & - & 二 & - & - - & 二 & - & 二. & - & - & $x-$ & $z-$ & & & $\bar{x}$ & $\bar{x} \underline{X}$ & VR \\
\hline $27 \mathrm{R}-1,74-77$ & & 308 & - & - & & $x-$ & - & - & $\bar{x}$ & -2 & $\bar{x}$ & - & $\mathrm{x}$ & $x \quad x$ & & - & & VR \\
\hline $4,60-64$ & & 312 & - & - & - & - & - & - & $\mathrm{X}$ & $\mathrm{x}-$ & - & - & $\mathrm{X}$ & - & -- & - & - & $\mathrm{R}$ \\
\hline $27 \mathrm{R}-6,25-28$ & & 31 & $\bar{x}$ & - & -- & -- & - & - & $\bar{x}$ & -8 & $\mathrm{X}$ & $\bar{x}$ & - & & -- & - & -- & \\
\hline $28 \mathrm{R}-1,5$ & P10- & 31 & $\mathrm{X}$ & - & $-x$ & $x-$ & - & - & $\mathrm{X}$ & -8 & $\mathrm{X}$ & $\mathrm{X}$ & - & & & - & & VR \\
\hline $28 \mathrm{R}-3,74-77$ & P12 & 321 & $\mathrm{X}$ & $\mathrm{X}$ & -- & $-\bar{x}$ & - & $\bar{v}$ & $\mathrm{X}$ & $\mathrm{X} \quad \mathrm{r}$ & & - & & & & - & - & $\mathrm{R} / \mathrm{C}$ \\
\hline & & & & $\bar{v}$ & $\bar{v} \mathrm{cf}$ & $f \quad x$ & $\mathrm{cf}$ & $\mathrm{X}$ & $\mathrm{x}$ & $\mathrm{X}$ & & - & - & & - & & & \\
\hline & & & $\mathrm{X}$ & $\mathrm{X}$ & $\mathrm{X}$ & $x-$ & - & & & & & - & - & & & & & (1) \\
\hline 132 & & 329. & - & - & - & - - & - & - & - & - & - & - & - & & - & - & - & $\mathrm{R}$ \\
\hline $30 \mathrm{I}$ & & 33 & - & - & -- & - - & - & - & - & - & - & - & - & & -- & - & -- & \\
\hline & & & - & & - & - & - & - & - & - & & - & & & - - & 二 & - & \\
\hline $\begin{array}{l}31 \mathrm{R}-1,80-83 \\
31 \mathrm{R}-3,9-12\end{array}$ & & 349.3 & 二 & & - & - & 二 & - & - & - & & - & - & - & - & - & 二 & $\begin{array}{l}\mathrm{VR} \\
\mathrm{VR}\end{array}$ \\
\hline
\end{tabular}

and the rotaliporids and $F$. washitensis must be interpreted as reworked. We believe the presence of possible rotaliporids more likely supports the first interpretation; thus, the initiation of pelagic sedimentation can be dated to the Cenomanian.

One specimen of $H$. helvetica was observed in Sample 160-967E31R-1, 5-9 cm, associated with common whiteinellids, Heterohelix, and very rare questionable dicarinellids. Specimens of marginotruncanids were not positively identified in this sample. Consequently, we assigned Section 160-967E-31R-1 to the lower part of the H. helvetica Zone of early Turonian age.

The next identifiable zone is the Dicarinellla concavata Zone in Interval 160-967E-30R-1, 55-59 cm, of late Turonian age (Robaszynski et al., 1990; Fig. 2; Table 2). Between this and the lower sample (interval 160-967E-31R-1, 5-9 cm), the very poor recovery $(<3 \%)$ prevents us from documenting the middle to upper part of the $H$. helvetica Zone and the Marginotruncana sigali Zone that extends up through the middle Turonian.

From the D. concavata Zone upsection to Sample 160-967E-8R2, 50-52 cm, nine planktonic foraminiferal zones were identified, spanning the interval from the upper Turonian to the upper Maastrichtian, as follows (from bottom to top):
Dicarinella concavata Zone (from 160-967E-30R-1, 55-59 cm, to 160-967E26R-CC; $>45 \mathrm{~m}$ )

Diagnosis: Interval from the first occurrence (FO) of the named species to the FO of Dicarinella asymetrica.

The zonal marker is common only in two samples from Core 160967E-29R and was not found in the upper part of the interval (Table 3 , back pocket). The planktonic foraminiferal assemblages are mainly composed of small-sized specimens $(<250 \mu \mathrm{m})$ associated with common to abundant, commonly broken benthic foraminifers. Planktonic foraminifers include common marginotruncanids (only a few identified at species level), whiteinellids, Heterohelix globulosa, and Globigerinelloides ultramicrus. Less common species with a more scattered record are Hedbergella flandrini and Heterohelix reussi, plus Globigerinelloides prairiehillensis in the upper part. Dicarinella canaliculata disappears before the end of the zone. Contusotruncana fornicata appears in Sample 160-967E-29R-1, 100-102 cm, and Sigalia decoratissima carpatica first occurs in Sample 160-967E-26RCC. Reworked assemblages from the $H$. helvetica Zone are recorded in Samples 160-967E-30R-1, 15-25 cm; 29R-2, 4-10 cm; and 29R$1,109-114 \mathrm{~cm}$. 


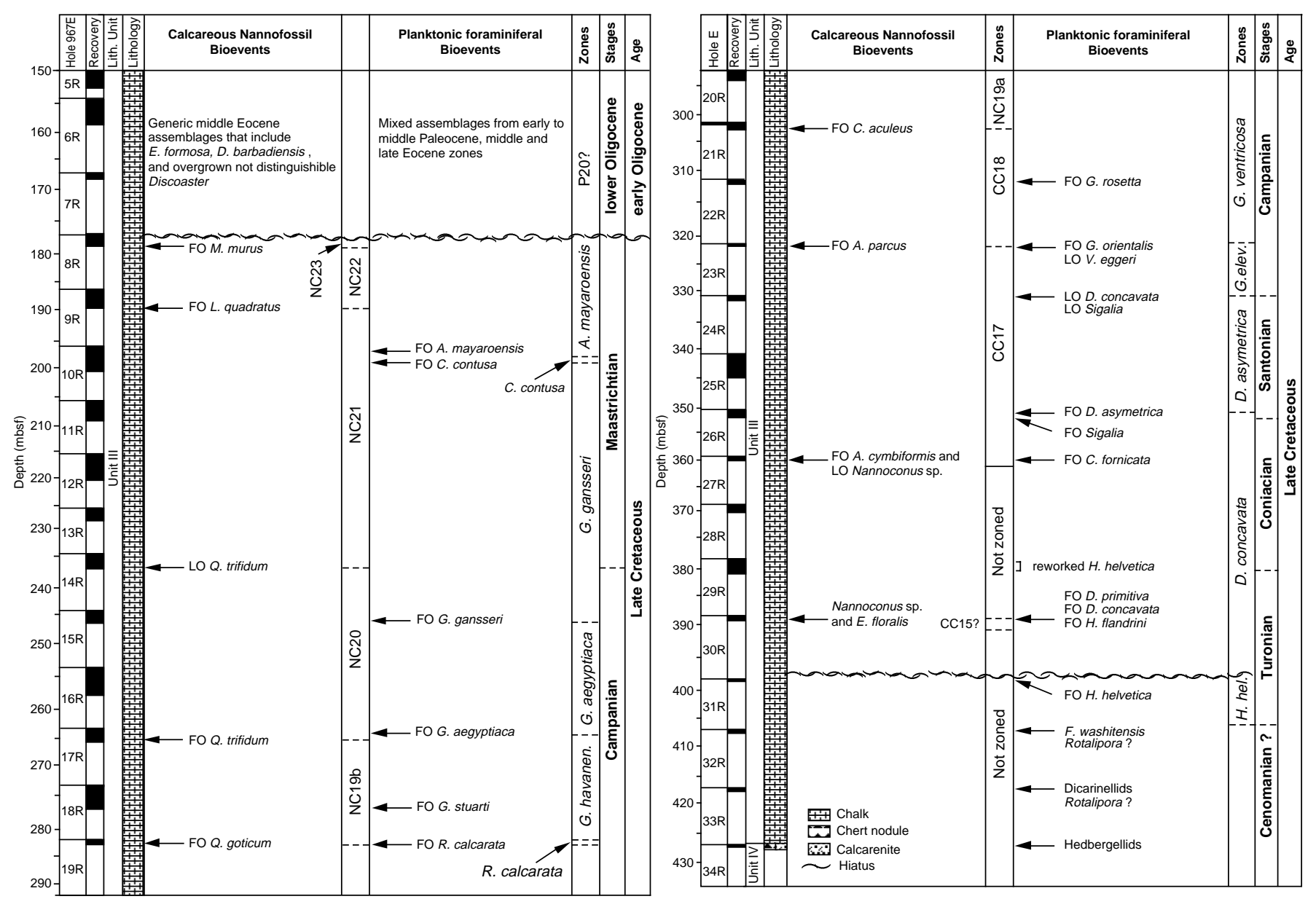

Figure 2. Lithologic log, core recovery, planktonic foraminiferal bioevents, and zone assignment plotted vs. calcareous nannofossil bioevents (after Emeis, Robertson, Richter, et al., 1996) in Hole 967E. Notes: FO = first occurrence, LO = last occurrence. The inferred hiatus between Cores 30R and 31R is arbitrarily placed at the base of Core 30R, and Core 31R was totally attributed to the H. helvetica Zone.

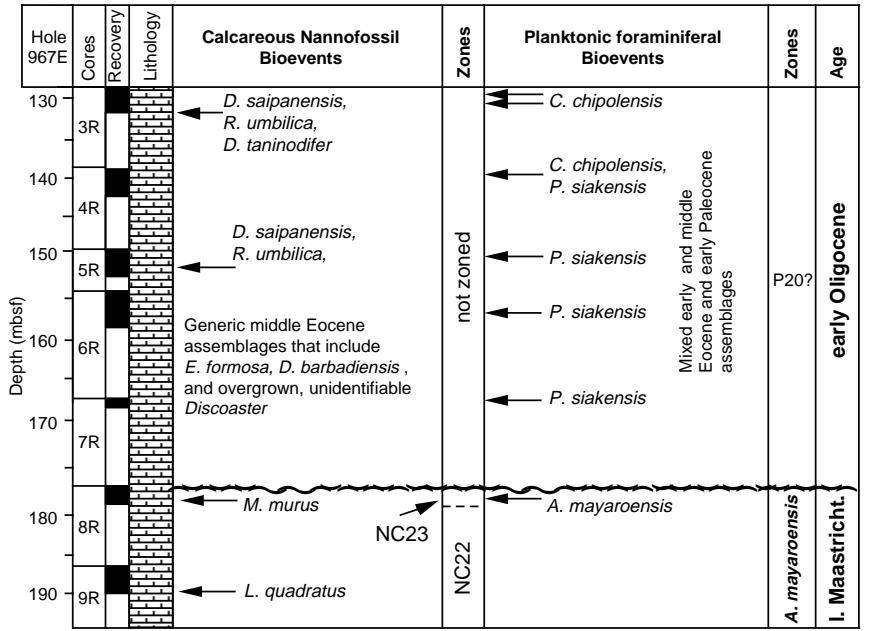

Figure 3. Expanded lithologic log and core recovery plotted vs. occurrence of planktonic foraminifers and zone assignment for the Oligocene succession recovered from Hole 967E. Note: Symbols same as in Figure 2.
Dicarinella asymetrica Zone (from 160-967E-26R-1, 50-58 cm, to 160-967E-24R; $19.58 \mathrm{~m})$

Diagnosis: Total range of the zonal marker.

The zonal marker was observed only in the lowermost sample of this zone, but $D$. concavata last occurs in Sample 160-967E-24R-1, $22-23 \mathrm{~cm}$, which was equated to the top of the zone. As in the previous zone, planktonic foraminiferal assemblages are mainly composed of small-sized specimens $(<250 \mu \mathrm{m})$ associated with common to abundant, often broken benthic foraminifers. The common marginotruncanids rarely could be identified at species level except for rare Marginotruncana pseudolinneiana, M. coronata, and M. sinuosa. Other common species are G. prairiehillensis, Globigerinelloides messinae, G. ultramicrus, $H$. globulosa, Heterohelix carinata, $H$. striata, and Ventilabrella eggeri. Sigalia decoratissima carpatica is scattered, and Sigalia deflaensis rugocostata occurs only in the upper part of the interval. Rare Hedbergella holmdelensis occurs throughout, whereas rare globotruncanids are recorded only in the middle to upper part of the zone.

Globotruncanita elevata Zone (Core 160-967E-23R; 8.82 m)

Diagnosis: Interval from the last occurrence (LO) of Dicarinella asymetrica and D. concavata to the FO of Globotruncana ventricosa. 
Table 2. Distribution of Lower Cretaceous shallow-water components and lower Upper Cretaceous planktonic foraminifers in Hole 967E.

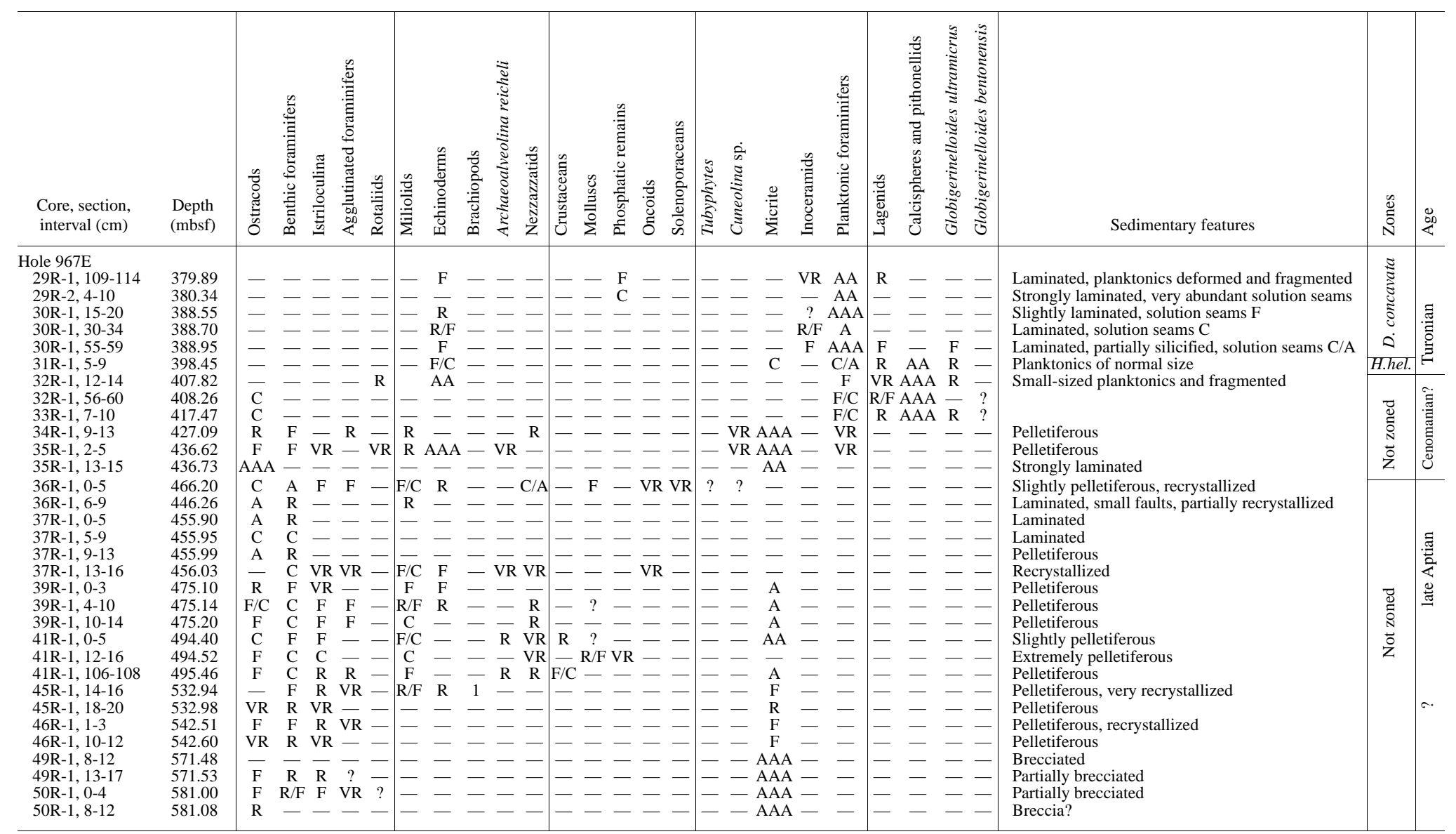

Note: Study conducted in thin sections. $1=$ one fragment; $\mathrm{X}=$ present; $\mathrm{VR}=$ very rare $(1-2$ specimens $) ; \mathrm{R}=$ rare $(2-5$ specimens $) ; \mathrm{C}=$ common $(10-30$ specimens $)$. 
Table 2 (continued).

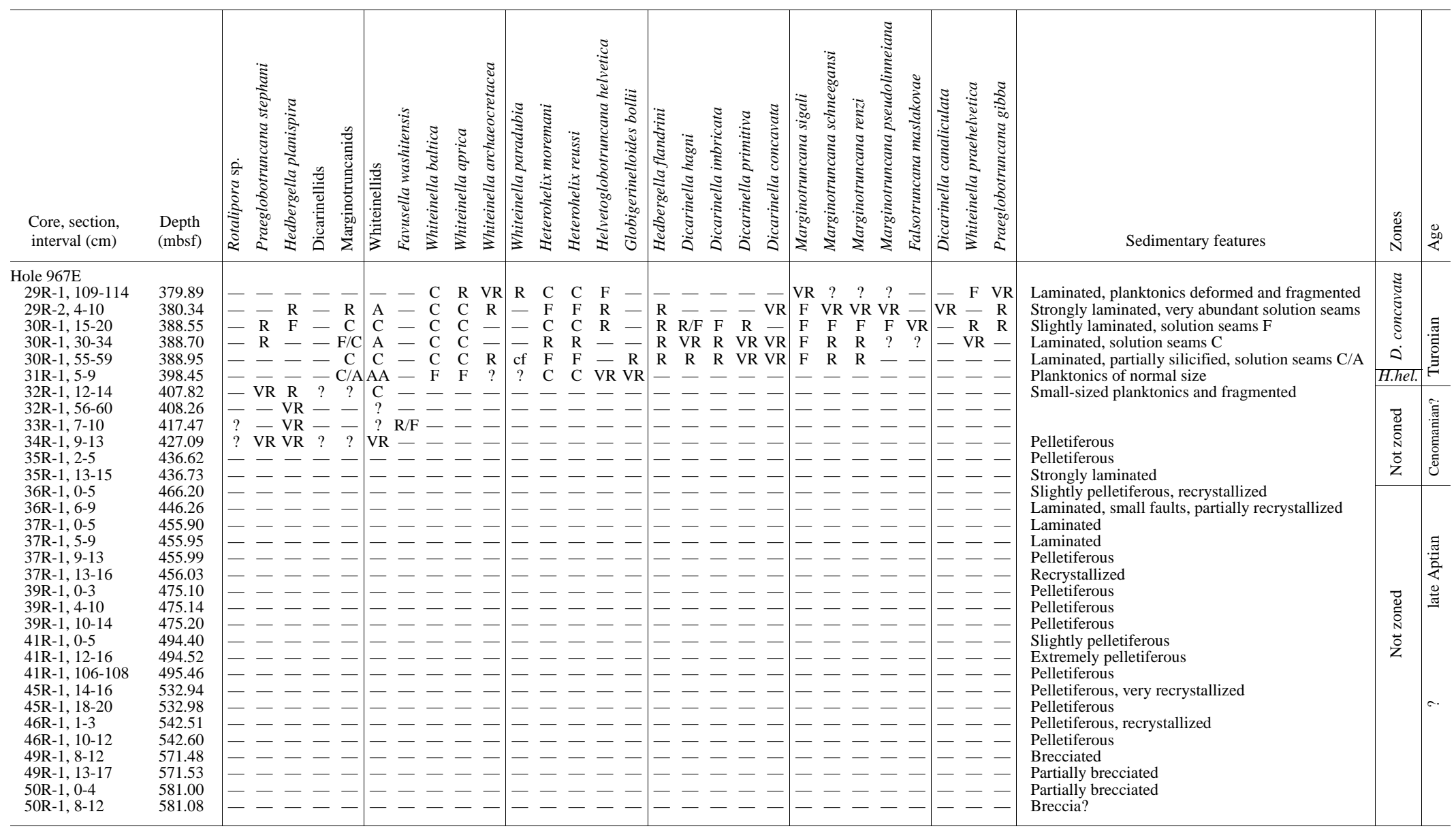


Planktonic foraminiferal assemblages exhibit a major change between Cores 160-967E-24R and 23R, with faunas in the latter core rich in globotruncanids along with common Globotruncanita stuartiformis, all of which are absent in Core 160-967E-24R. The assemblage in Sample 160-967E-23R-CC contains V. eggeri and $M$. pseudolinneiana in association with Globotruncana orientalis. According to Caron (1985) and Nederbragt (1990) the co-occurrence of these species is indicative of the G. elevata Zone, although the zonal marker was never found in Hole 967E.

This zonal assignment is in agreement with the Campanian age inferred from calcareous nannofossils: Sample 160-967E-23R-CC yielded the nannofossil Aspidiscus parcus, which identifies the early Campanian CC18 Zone (Emeis, Robertson, Richter, et al., 1996) (Fig. 2). Owing to the poor recovery and size-sorting that affects all the assemblages, we attribute to the G. elevata Zone only Core 160967E-23R.

Globotruncana ventricosa Zone (from 160-967E-22R-CC to 160967E-20R-CC; $37.8 \mathrm{~m}$ ).

Diagnosis: Interval from the FO of the zonal marker to the FO of $R a$ dotruncana calcarata.

The zonal marker Globotruncana ventricosa was identified with certainty only much higher in the following zone. In the absence of the zonal marker, zonal attribution was based on the appearance of Globotruncana rosetta in Sample 160-967E-22R-1, 19-22 cm, in association with Globotruncana arca, G. orientalis, G. linneiana, and G. mariei. Above this level, several species first appear in succession, such as Pseudotextularia elegans and Globigerinelloides alvarezi in Sample 160-967E-21R-CC, and Contusotruncana plummerae and $C$. patelliformis in Sample 160-967E-21R-1, 46-48 cm. According to Robaszynski et al. (1984), Caron (1985), and Premoli Silva and Sliter (1994) the successive appearances of the aforementioned species are recorded within the $G$. ventricosa Zone.

Radotruncana calcarata Zone (from 160-967E-19R-CC to 160967E-19R-1, 69-71 cm; $1.1 \mathrm{~m})$

Diagnosis: Total range of the zonal marker.

Rare specimens of the named taxon were identified in both samples from Core 160-967E-19R. The assemblages are very similar to those from the previous zone. In addition to the species inherited from the $G$. ventricosa Zone, common $G$. ventricosa and abundant Pseudoguembelina costulata were also found.

Globotruncanella havanensis Zone (from 160-967E-18R-3, 51-53 $\mathrm{cm}$, to $160-967 \mathrm{E}-17 \mathrm{R}-2,127-134 \mathrm{~cm} ; 18.62 \mathrm{~m}$ )

Diagnosis: Interval from the LO of Radotruncana calcarata to the FO of Globotruncana aegyptiaca.

This zone was identified according to its definition, although in the absence of the zonal marker. Several additional species are recorded at the base of this zone, such as Globotruncanita stuarti, Globotruncana falsostuarti, Globotruncanella minuta, and the rugoglobigerinids, followed above by the appearance of Ventilabrella multicamerata, Heterohelix punctulata, and Rugoglobigerina rugosa. Heterohelix carinata is last recorded at the base of the zone.

Globotruncana aegyptiaca Zone (from 160-967E-17R-1, 117-120 $\mathrm{cm}$, to $160-967 \mathrm{E}-15 \mathrm{R}-3,30-34 \mathrm{~cm} ; 17.72 \mathrm{~m})$

Diagnosis: Interval from the FO of the zonal marker to the FO of Gansserina gansseri.

The zonal marker is rare. Several additional species were found in this zone such as Laeviheterohelix dentata, Pseudoguembelina palpebra, Rugoglobigerina macrocephala, and Globotruncanella havanensis at the base, followed by Heterohelix planata, Globotrun- canella pschadae, and Heterohelix labellosa, Rugoglobigerina hexacamerata, and $R$. pennyi in the upper part of the zone.

The overall preservation of planktonic faunas improves in this interval and size-sorting is less marked.

Gansserina gansseri Zone (from 160-967E-15R-2, 122-124 cm, to 160-967E-10R-3, 60-62 cm; $48.05 \mathrm{~m}$ )

Diagnosis: Interval from the FO of the zonal marker to the FO of Contusotruncana contusa.

The zonal marker is very rare and scattered throughout the zone. Abathomphalus intermedius and Planoglobulina carseyae appear at the base of the zone, followed by the FO of Globotruncanita pettersi, Kuglerina rotundata, Pseudoguembelina excolata, Gansserina wiedenmayeri, Globotruncana esnehensis, Globotruncanita conica, Gublerina acuta, Pseudotextularia nuttalli, and Gublerina cuvillieri. Close to the top of the zone, Planoglobulina acervulinoides, Pseudotextularia intermedia, and Plummerita hantkeninoides are also recorded. Globigerinelloides bollii disappears in the middle part of the zone followed slightly higher by the disappearance of G. prairiehillensis.

Contusotruncana contusa/Racemiguembelina fructicosa Zone (from 160-967E-10R-3, 0-4 cm, to 160-967E-10R-2, 0-3 cm; $1.56 \mathrm{~m}$ )

Diagnosis: Interval from the FO of the zonal markers to the FO of Abathomphalus mayaroensis.

The lower boundary of this short zone was identified by the presence of the first of the two markers only, whereas the second marker appears just prior to the end of the zone. Contusotruncana plummer$a e$ and Heterohelix rajagopalani disappear at the end of the zone.

Abathomphalus mayaroensis Zone (from 160-967E-10R-1, 114-117 $\mathrm{cm}$, to $160-967 \mathrm{E}-8 \mathrm{R}-2,50-52 \mathrm{~cm} ; 19.04 \mathrm{~m}$ )

Diagnosis: Interval from the FO of the zonal marker to the extinction of most of the Cretaceous planktonic foraminifers, almost equated to the total range of the zonal marker.

The zonal marker is rather common throughout the zone. Preservation becomes increasingly poor toward the top, and in the uppermost sample the assemblage is composed mainly of small-sized heterohelicids or fragmented $P$. elegans. The rotaliforms are practically absent above Sample 160-967E-8R-CC.

The first sample belonging to the Tertiary is Sample 160-967E$8 \mathrm{R}-1,92-94 \mathrm{~cm}$, which contains a strongly mixed assemblage that spans the interval from the earliest Paleocene Zone Palpha to the late early Oligocene.

\section{Oligocene Planktonic Foraminifers}

Oligocene planktonic foraminiferal assemblages are scarce and poorly preserved throughout (Sample 160-967E-8R-1, 92-94 cm, to 3R-1, 57-59 cm) (Fig. 3). The sedimentary sequence cannot be attributed to an interval older than the early Oligocene, possibly Zone P20, based on the presence of Cassigerinella chipolensis and Paragloborotalia siakensis in several samples. Oligocene specimens are, however, very rare and overwhelmed by reworked specimens.

Reworking includes the typical middle Eocene planktonic species previously observed in Hole $966 \mathrm{~F}$, together with common early to mid-Paleocene and early Eocene forms such as, Parvularugoglobigerina eugubina, Globanomalina planocompressa, Globoconusa daubjergensis, Praemurica uncinata, Praemurica praecursoria, Subbotina triloculinoides, Parasubbotina pseudobulloides, Acarinina mckannai, Morozovella angulata (Paleocene Zones Palpha to P3b); Acarinina nitida, Morozovella quetra, M. gracilis, M. subbotinae, M. occlusa (early Eocene Zones P6b to P7); and Acarinina cuneicamerata and A. spinuloinflata (middle Eocene Zones P10-P11). 
There is no evidence of planktonic foraminiferal assemblages attributable to the late Paleocene, late early Eocene, latest Eocene, and probably earliest Oligocene. Because of the strong reworking, no range chart was produced for this hole.

\section{Cretaceous Sedimentation Rate}

To identify the presence of possible hiatuses, owing to the nondocumentation of some zones and the overall poor recovery, a mean sedimentation rate of $8.17 \mathrm{~m} / \mathrm{m}$.y. was estimated for the entire sequence from the $H$. helvetica Zone to the A. mayaroensis Zone (178.0-407.7 mbsf; total thickness, $229.7 \mathrm{~m}$ ) (Fig. 4), based on the time scale of Erba et al. (1995). As shown in Figure 4 (see also Table 4), the sedimentation rate varies from zone to zone. In particular, very low rates are apparent in the G. elevata $(2.38 \mathrm{~m} / \mathrm{m} . \mathrm{y}),$.$R . calcarata$ $(2.02 \mathrm{~m} / \mathrm{m} . \mathrm{y}$.), and C. contusa $(1.04 \mathrm{~m} / \mathrm{m} . \mathrm{y}$.) Zones. It is worth mentioning that the zonal markers of these three zones are usually largesized forms $(>250 \mu \mathrm{m})$. As described above, most of the larger fractions of the residues were removed by either winnowing or resedimentation favoring the accumulation of smaller species and specimens. Consequently, what we observed was probably not the true range of the marker species, resulting in an underestimation of the thickness of the single zones and an artificially low sedimentation rate. Recalculating the sedimentation rates for the intervals from the base of the G. gansseri Zone to the top of the A. mayaroensis Zone, and from the base of the G. elevata Zone to the base of the G. gansseri Zone, we obtained sedimentation rates close to the mean value (8.73 $\mathrm{m} / \mathrm{m} . \mathrm{y}$. and $8.08 \mathrm{~m} / \mathrm{m} . \mathrm{y}$., respectively). This recalculation supports the continuity of sedimentation during the Campanian-Maastrichtian (Fig. 4).

In the sequence below the G. elevata Zone, the D. asymetrica Zone displaces a sedimentation rate slightly higher than the mean value $(9.32 \mathrm{~m} / \mathrm{m} . \mathrm{y}$.), whereas a sedimentation rate higher than $11.0 \mathrm{~m} /$ m.y. was estimated for the $D$. concavata Zone, the best documented zone.

The $D$. concavata Zone directly overlies the lower part of the $H$. helvetica Zone. As described above, the $M$. sigali Zone and the middle to upper part of the $H$. helvetica Zone were not identified. The calculation of the sedimentation rate assuming that the $H$. helvetica Zone is totally represented resulted in a value much lower than the mean rate $(3.87 \mathrm{~m} / \mathrm{m} . \mathrm{y}$.). Recalculating the sedimentation rate for the interval from the top of the $D$. concavata Zone to the supposed base of the $H$. helvetica Zone, we obtained a sedimentation rate of $5.97 \mathrm{~m} /$ m.y., a value still lower than the mean rate. This suggests that the $M$. sigali Zone and the middle to upper part of the H. helvetica Zone may indeed be missing.

\section{Cretaceous Isotope Stratigraphy}

Oxygen and carbon isotopes were measured in bulk samples in order to tentatively compare the Hole $967 \mathrm{E}$ record with the isotope curves previously obtained in continuous and well-dated land sections (Corfield et al., 1991; Jenkyns et al., 1994). As shown in Figure 5 , the stratigraphic resolution is rather poor, especially in the lower part of the sedimentary sequence below the $R$. calcarata Zone, owing to very poor recovery.

The oxygen and carbon curves frequently display opposite trends (see also Table 5). This may suggest that diagenesis altered little of the primary signals (Corfield et al., 1991). The oxygen curve shows a trend toward more positive values from the bottom to the top of the pelagic sequence, and the carbon curve shows more constant values with low amplitude fluctuations throughout, a pattern similar to that observed by Corfield et al. (1991) in the Bottaccione section (Gubbio, Italy). Two negative carbon peaks in the $D$. concavata Zone may correspond to the negative peaks shown by Jenkyns et al. (1994), with the lower one equated to the base of the Coniacian. This lower shift is used to place the base of the Coniacian as shown in Figure 4. The other two negative carbon peaks, at the base of the $G$. havanensis Zone (late Campanian) and in the lower part of the G. gansseri Zone (early Maastrichtian), may correlate with those identified by Corfield et al. (1991) as reinterpreted according to Premoli Silva and Sliter (1994). The prominent negative carbon shift related to the Bonarelli Event (latest Cenomanian) (Corfield et al., 1991; Jenkyns et al., 1994) was not recorded in Hole 967E.

Shallow-water sediments and sediments transitional between shallow-water carbonates and pelagic chalk display more negative oxygen and carbon isotope values. The more negative carbon isotope value is consistent with the late Aptian age attributed to the upper part of the carbonate platform and seems to correspond to the negative shift observed close to the Aptian/Albian boundary in the Italian pelagic sequences as reported in Erba (1996).

\section{SUMMARY AND CONCLUSIONS}

Despite the poor recovery, poor preservation of planktonic foraminifers, intense winnowing, and some reworking, Leg 160 recovered a relatively continuous Upper Cretaceous pelagic succession from the lower slope of the Eratosthenes Seamount. Only the M. sigali Zone and the middle to late $H$. helvetica Zone of middle Turonian age were not documented. The very low rate of sedimentation estimated from the top of the D. concavata Zone (early Santonian) to the base of the $H$. helvetica Zone (early Turonian) suggests that the $M$. sigali Zone and the middle to late $H$. helvetica Zone are probably missing.

Below the lower $H$. helvetica Zone, biostratigraphic resolution is very poor owing to sparse planktonic foraminifers and the apparent absence of calcareous nannofossils. However, the initiation of pelagic sedimentation on the seamount can probably be dated to the midCenomanian. The top of the shallow-water carbonate unit is well dated to the late Aptian based on the presence of Archaealveolina reicheli. The same age-diagnostic larger foraminifer is reworked within the lowermost pelagic layers. There is no evidence that sediments of Albian to early Cenomanian age were ever deposited. This suggests that shallow-water deposition ended in the late Aptian, and a hiatus probably spans the entire Albian and part of the Cenomanian. The lower part of the shallow-water sequence cannot be dated.

Another major hiatus marks the Cretaceous/Tertiary boundary, with early Oligocene sediments resting on those of the late Maastrichtian. However, from the reworked assemblages we can infer that deposition on the seamount was much more complete: in fact, the lower to mid-Paleocene, and parts of the lower and middle Eocene could be documented. The missing upper Paleocene, part of the lower Eocene, and upper Eocene were either not deposited or were removed to lower levels in the basin and bypassed the Site 967 location. The heavy reworking may indicate tectonic instability or a higher energy environment during the early Oligocene.

Pelagic sedimentation occurred atop the seamount in the middle Eocene as indicated by the rather undisturbed pelagic record recovered in Hole 966F. At this topographically higher location, however, pelagic sedimentation was much less continuous than in the lower slope, suggesting that the Site 966 location was possibly the source area of the downslope reworked material.

Stable isotope stratigraphy (oxygen and carbon) tentatively allows comparison of the Cretaceous isotope record of Hole 967E with continuous and well-dated land sections in central Italy. One of the negative carbon isotope peaks was recognized as indicative of the base of the Coniacian.

\section{ACKNOWLEDGMENTS}

The second author is indebted to ODP for inviting her to participate in Leg 160. The authors would like to thank Maurizio Chiocchini 


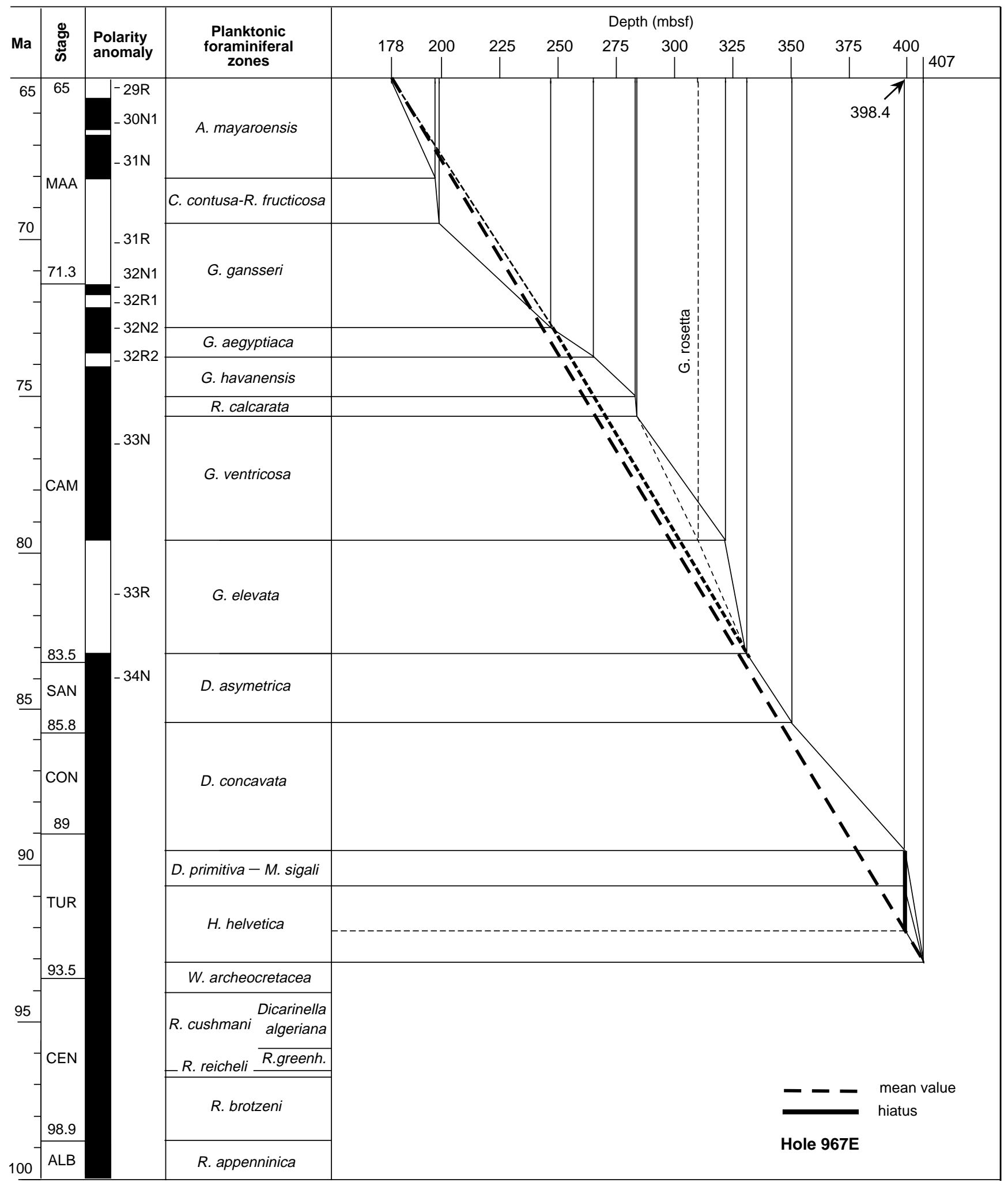

Figure 4. Sedimentation rate of the Cretaceous succession recovered from Hole 967E plotted vs. planktonic foraminiferal zonal scheme, magnetic polarity, and time scale from Erba et al. (1995). See text section "Cretaceous Sedimentation Rate," for explanation. 
Table 4. Cretaceous planktonic foraminiferal zones vs. their thickness and sedimentation rate, Hole 967E.

\begin{tabular}{lcc}
\hline $\begin{array}{c}\text { Cretaceous planktonic } \\
\text { foraminiferal zones }\end{array}$ & $\begin{array}{c}\text { Thickness } \\
(\mathrm{m})\end{array}$ & $\begin{array}{c}\text { Sedimentation } \\
\text { rate }(\mathrm{m} / \mathrm{m} . \mathrm{y} .)\end{array}$ \\
\hline A. mayaroensis & 19.00 & 6.33 \\
C. contusa & 1.56 & 1.04 \\
G. gansseri & 48.05 & 13.73 \\
G. aegyptiaca & 17.72 & 17.72 \\
G. havanensis & 18.72 & 12.48 \\
R. calcarata & 1.01 & 2.02 \\
G. ventricosa & 37.80 & 9.45 \\
G. elevata & 8.82 & 2.38 \\
D. asymetrica & 19.58 & 9.32 \\
D. concavata & $>45.0$ & $>11.0$ \\
H. helvetica & 9.30 & 3.87 \\
& & \\
\hline
\end{tabular}

Notes: Time scale after Erba et al. (1995). The thickness of $D$. concavata Zone is poorly constrained because of the very poor recovery.

for his help and suggestions concerning the interpretation of shallowwater facies. W.V. Sliter and B. Huber are greatly acknowledged for reviewing the paper. This research was partially supported by the Italian Consiglio Nazionale delle Ricerche CT Grant no. 94.00168.CT05 to M.B. Cita.

\section{REFERENCES}

Arnaud Vanneau, A., and Premoli Silva, I., 1995. Biostratigraphy and systematic description of benthic foraminifers from mid-Cretaceous shallow-water carbonate platform sediments at Sites 878 and 879 (MIT and Takuyo-Daisan Guyots). In Haggerty, J.A., Premoli Silva, I., Rack, F., and McNutt, M.K. (Eds.), Proc. ODP, Sci. Results, 144: College Station, TX (Ocean Drilling Program), 199-219.

Blow, W.H., 1969. Late middle Eocene to Recent planktonic foraminiferal biostratigraphy. In Brönnimann, P., and Renz, H.H. (Eds.), Proc. First Int. Conf. Planktonic Microfossils, Geneva, 1967: Leiden (E.J. Brill), 1:199-422.

1979. The Cainozoic Globigerinida: Leiden (E.J. Brill).

Boersma, A., and Premoli-Silva, I., 1983. Paleocene planktonic foraminiferal biogeography and the paleoceanography of the Atlantic Ocean. Micropaleontology, 29:355-381.

Boersma, A., Premoli Silva, I., and Shackleton, N.J., 1987. Atlantic Eocene planktonic foraminiferal paleohydrographic indicators and stable isotope paleoceanography. Paleoceanography, 2:287-331.

Caron, M., 1985. Cretaceous planktic foraminifera. In Bolli, H.M., Saunders, J.B., and Perch-Nielsen, K. (Eds), Plankton Stratigraphy: Cambridge (Cambridge Univ. Press), 17-86.

Corfield, R.M., Cartlidge, J.E., Premoli Silva, I., and Housley, R.A., 1991. Oxygen and carbon isotope stratigraphy of the Palaeogene and Cretaceous limestones in the Bottaccione Gorge and the Contessa Highway sections, Umbria, Italy. Terra Nova, 3:414-422.

Craig, H., 1957. Isotopic standards for carbon and oxygen and correction factors for mass-spectrometric analysis of carbon dioxide. Geochim. Cosmochim. Acta, 12:133-149.

De Castro, P., 1966. Contributo alla conoscenza delle Alveoline albiano-cenomaniane della Campania. Boll. Soc. Natural. Napoli, 75:1-59.

Emeis, K.-C., Robertson, A.H.F., Richter, C., et al., 1996. Proc. ODP, Init. Repts., 160: College Station, TX (Ocean Drilling Program).

Erba, E., 1996. The Aptian Stage. In Rawson, P.F., Dhondt, A.V., Hancock, J.M., and Kennedy, W.J. (Eds.), Proc. 2nd Int. Symp. on Cretaceous Stage Boundaries, 8-16 Sept. 1995. Bull. Inst. R. Sci. Nat. Belg., 66 (Suppl.):31-43.

Erba, E., Premoli Silva, I., Wilson, P.A., Pringle, M.S., Sliter, W.V., Watkins, D.K., Arnaud Vanneau, A., Bralower, T.J., Budd, A.F., Camoin, G.F., Masse, J.-P., Mutterlose, J., and Sager, W.W., 1995. Synthesis of stratigraphies from shallow-water sequences at Sites 871 through 879 in the western Pacific Ocean. In Haggerty, J.A., Premoli Silva, I., Rack, F., and McNutt, M.K. (Eds.), Proc. ODP, Sci. Results, 144: College Station, TX (Ocean Drilling Program), 873-885.

Fourcade, E., 1980. Archaealveolina decastroi n. gen. n. sp. Foraminifère nouveau de l' Aptien supérieur de l' Ile d'Ibiza (Espagne). Rev. Micropaleontol., 23:67-75.

Hemleben, C., Muhlen, D., Olsson, R.K., and Berggren, W.A., 1991. Surface texture and the first occurrence of spines in planktonic foraminifera from the early Tertiary. Geol. Jahrb., 128:117-146.
Jenkyns, H.C., Gale, A.S., and Corfield, R.M., 1994. Carbon- and oxygenisotope stratigraphy of the English Chalk and Italian Scaglia and its palaeoclimatic significance. Geol. Mag., 131:1-34.

Loeblich, A.R., Jr., and Tappan, H., 1988. Foraminiferal Genera and Their Classification: New York (Van Nostrand Reinhold).

Nederbragt, A.J., 1990. Biostratigraphy and paleoceanographic potential of the Cretaceous planktic foraminifera Heterohelicidae. [Doctoral dissert.]. Centrale Huisdrukkerij Vrije Univ., Amsterdam.

Olsson, R.K., Hemleben, C., Berggren, W.A., and Liu, C., 1992. Wall texture classification of planktonic Foraminifera Genera in the lower Danian. $J$. Foraminiferal Res., 22:195-213.

Pessagno, E.A., 1967. Upper Cretaceous planktonic foraminifera from the western Gulf Coastal Plain. Paleontograph. Am., 5:245-445.

Premoli Silva, I., and Boersma, A., 1988. Atlantic Eocene planktonic foraminiferal historical biogeography and paleohydrographic indices. Palaeogeogr., Palaeoclimatol., Palaeoecol., 67:315-356.

1989. Atlantic Paleogene planktonic foraminiferal bioprovincial indices. Mar. Micropaleontol., 14:357-371.

Premoli Silva, I., and Sliter, W.V., 1994. Cretaceous planktonic foraminiferal biostratigraphy and evolutionary trends from the Bottaccione Section, Gubbio, Italy. Palaeontogr. Ital., 82:2-90.

Robaszynski, F., and Caron, M., 1995. Foraminifères planctoniques du Crétacé: commentaire de la zonation Europe-Méditerranée. Bull. Soc. Geol. Fr., 166:681-692.

Robaszynski, F., Caron, M., Dupuis, C., Amedro, F., Gonzales-Donoso, J.M., Linares-Rodriguez, D., Hardenbol, J., Gartner, S., Calandra, F., and Deloffre, R., 1990. A tentative integrated stratigraphy in the Turonian of Central Tunisia: formations, zones and sequential stratigraphy in the Kalaat Senan area. Bull. Cent. Res. Expl.-Prod. ELF-Aquitaine, 14:213384.

Robaszynski, F., Caron, M. (Coord.), and the European Working Group on Planktonic Foraminifera, 1979. Atlas de Foraminifères Planctoniques du Crétacé Moyen (Vols. 1 and 2). Cah. Micropaleontol.

Robaszynski, F., Caron, M., Gonzales-Donoso, J.-M., Wonders, A.A.H., and the European Working Group on Planktonic Foraminifera, 1984. Atlas of Late Cretaceous globotruncanids. Rev. Micropaleontol., 26:145-305.

Robaszynski, F., Hardenbol, J., Caron, M., Amédro, F., Dupuis, C., González Donoso, J.-M., Linares, D., and Gartner, S., 1993. Sequence stratigraphy in a distal environment: the Cenomanian of the Kalaat Senan region (central Tunisia). Bull. Cent. Rech. Explor-Prod. Elf-Aquitaine, 17:395433.

Spezzaferri, S., 1994. Planktonic foraminiferal biostratigraphy and taxonomy of the Oligocene and lower Miocene in the oceanic record: an overview. Palaeontographia Ital., 81:1-187.

Toumarkine, M., and Luterbacher, H., 1985. Paleocene and Eocene planktic foraminifera. In Bolli, H.M., Saunders, J.B., and Perch-Nielsen, K. (Eds.), Plankton Stratigraphy: Cambridge (Cambridge Univ. Press), 87154.

Date of initial receipt: 7 January 1997
Date of acceptance: 10 August 1997

Ms 160SR-022

\section{LIST OF SPECIES}

Species are listed in alphabetical order by genus.

\section{List of Paleogene Species}

The generic and specific concepts and the species groups used by Boersma and Premoli Silva (1983), Boersma at al. (1987), Olsson et al. (1992), Premoli Silva and Boersma $(1988,1989)$, and Spezzaferri (1994) are retained herein, whenever possible.

Acarinina bullbrooki (Bolli, 1957) (= Globorotalia bullbrooki Bolli)

Acarinina matthewsae (Blow, 1979) (= Globorotalia (Acarinina) matthewsae Blow)

Acarinina pentacamerata Subbotina, 1953

Acarinina primitiva (Finlay, 1939) (= Globoquadrina primitiva Finlay)

Acarinina pseudotopilensis Subbotina, 1953

Acarinina rugosoaculeata Subbotina, 1953

Cassigerinella chipolensis (Cushman and Ponton, 1932) (= Cassidulina chipolensis Cushman and Ponton)

Catapsydrax unicavus Bolli, Loeblich and Tappan, 1957

Chiloguembelina cubensis (Palmer, 1934) (= Guembelina cubensis Palmer). 
Dentoglobigerina galavisi (Bermudez, 1961) (= Globigerina galavisi Bermudez) "Globigerina" venezuelana Hedberg, 1937

Globigerinatheka index (Finlay, 1939) (= Globigerinoides index Finlay)

Globigerinatheka luterbacheri Bolli, 1972

Globigerinatheka micra (Shutskaya, 1958) (= Globigerinoides subconglobatus var. micra Shutskaya)

Globigerinatheka subconglobata (Shutskaya, 1958) (= Globigerinoides subconglobatus Chalilov var. subconglobata Chalilov).

Globorotaloides carcosellensis Toumarkine and Bolli, 1975

Morozovella aragonensis (Nuttall, 1930) (= Globorotalia aragonensis Nuttall)

Igorina broedermanni (Cushman and Bermudez) $(=$ Globorotalia (Truncorotalia) broedermanni Cushman and Bermudez)

Morozovella lenheri (Cushman and Jarvis, 1929) (= Globorotalia lenheri Cushman and Jarvis)

Paragloborotalia siakensis (LeRoy, 1939) (= Globorotalia siakensis LeRoy)

Globanomalina pseudoscitulus (Glaessner, 1937) (= Globorotalia pseudoscitula Glaessner)

Pseudohastigerina micra (Cole, 1927) (= Nonion micrus Cole)

Subbotina angiporoides angiporoides (Hornibrook, 1965) (= Globigerina angiporoides Hornibrook)

Subbotina angiporoides minima (Jenkins, 1966) (= Globigerina angiporoides Hornibrook subsp. minima Jenkins)

Subbotina eocaena (Guembel, 1868) (= Globigerina eocaena Guembel).

Subbotina hornibrooki (Brönnimann, 1952) (= Globigerina hornibrooki, Brönnimann)

Subbotina inaequispira (Subbotina, 1953) (= Globigerina inaequispira Subbotina)

Subbotina linaperta (Finlay, 1939) (= Globigerina linaperta Finlay).

Subbotina praeturritilina (Blow and Banner, 1962) (= Globigerina turritilina praeturritilina Blow and Banner).

Subbotina utilisindex (Jenkins and Orr, 1973) (= Globigerina utilisindex Jenkins and Orr)

Tenuitella gemma (Jenkins, 1971) (= Globorotalia (Turborotalia) gemma Jenkins)

Truncorotaloides rohri Brönnimann and Bermudez, 1953

Truncorotaloides topilensis (Cushman, 1925) (= Globigerina topilensis Cushman)

Turborotalia boweri $($ Bolli, 1957) $(=$ Globorotalia boweri Bolli)

Turborotalia cerroazulensis (Cole, 1928) (= Globigerina cerro-azulensis Cole)

Turborotalia griffinae Blow, 1979

Turborotalia pomeroli (Toumarkine and Bolli, 1970) (= Globorotalia cerroazulensis pomeroli Toumarkine and Bolli)

Turborotalia praecentralis Blow, 1979

Turborotalia pseudoampliapertura (Blow and Banner, 1962) (= Globigerina pseudoampliapertura Blow and Banner).

Turborotalia pseudomayeri (Bolli, 1959) (= Globigerina pseudomayeri Bolli)

Zeaglobigerina ampliapertura (Bolli, 1957) (= Globigerina ampliapertura Bolli)

\section{List of Cretaceous Species}

The generic and specific concepts follow Pessagno (1967), Robaszynski et al. (1979, 1984, 1990), Caron (1985), Loeblich and Tappan (1988), Nederbragt (1990), and Premoli Silva and Sliter (1994).

Abathomphalus intermedius (Bolli, 1951) (= Globotruncana intermedia Bolli) Abathomphalus mayaroensis (Bolli, 1951) (= Globotruncana mayaroensis Bolli)

Archaeoglobigerina blowi Pessagno, 1967

Archaeoglobigerina cretacea (d' Orbigny, 1840) (= Globigerina cretacea d' Orbigny)

Biglobigerinella multispina Lalicker, 1948

Clavihedbergella simplex (Morrow, 1934) (= Hastigerinella simplex Morrow)

Contusotruncana contusa (Cushman, 1926) (= Pulvinulina arca var. contusa Cushman)

Contusotruncana fornicata (Plummer, 1921) (= Globotruncana fornicata Plummer)

Contusotruncana patelliformis (Gandolfi, 1955) (= Globotruncana patelliformis Gandolfi)

Contusotruncana plicata (White, 1928) (= Globotruncana conica var. plicata White)

Contusotruncana plummerae (Gandolfi, 1955) (= Globotruncana plummerae Gandolfi)

Dicarinella asymetrica (Sigal, 1952) (= Globotruncana asymetrica Sigal)

Dicarinella canaliculata (Reuss, 1854) (= Rosalina canaliculata Reuss)
Dicarinella concavata (Brotzen, 1934) (= Rotalia concavata Brotzen)

Dicarinella hagni (Scheibnerova, 1962) (= Praeglobotruncana hagni Scheibnerova)

Dicarinella imbricata (Mornod, 1949) (= Globotruncana imbricata Mornod)

Dicarinella primitiva (Dalbiez, 1955) (= Globotruncana ventricosa subsp. primitiva Dalbiez)

Falsotruncana maslakovae Caron, 1981

Favusella washitensis (Carsey, 1926) (= Globigerina washitensis Carsey)

Gansserina gansseri (Bolli, 1951) (Globotruncana gansseri Bolli)

Gansserina wiedenmayeri (Gandolfi, 1955) (= Globotruncana wiedenmayeri Gandolfi)

Globigerinelloides alvarezi (Eternod Olvera, 1959) (= Planomalina alvarezi Eternod Olvera)

Globigerinelloides asper (Ehrenberg, 1854) (= Phanerostomum asperum Ehrenberg)

Globigerinelloides bentonensis (Morrow, 1934) (= Anomalina bentonensis Morrow)

Globigerinelloides bollii Pessagno, 1967

Globigerinelloides caseyi (Bolli, Loeblich and Tappan, 1957) (= Planomalina caseyi Bolli, Loeblich and Tappan)

Globigerinelloides messinae (Brönnimann, 1952) (= Globigerinella messinae Brönnimann)

Globigerinelloides prairiehillensis Pessagno, 1967

Globigerinelloides subcarinatus (Brönnimann, 1952) (= Globigerinella messinae subcarinata Brönnimann)

Globigerinelloides ultramicrus (Subbotina, 1949) (= Globigerinella ultramicra Subbotina)

Globotruncana aegyptiaca Nakkady, 1950

Globotruncana arca (Cushman, 1926) (= Pulvinulina arca Cushman)

Globotruncana bulloides Vogler, 1941

Globotruncana dupeuplei Caron, Gonzales Donoso, Robaszynski and Wonders, 1984

Globotruncana esnehensis Nakkady, 1950

Globotruncana falsostuarti Sigal, 1952

Globotruncana insignis Gandolfi, 1955

Globotruncana lapparenti Brotzen, 1936

Globotruncana linneiana (d' Orbigny, 1839) (= Rosalina linneiana d' Orbigny)

Globotruncana mariei Banner and Blow, 1960

Globotruncana orientalis El Naggar, 1966

Globotruncana rosetta (Carsey, 1926) (= Globigerina rosetta Carsey)

Globotruncana rugosa (Marie, 1941) (= Rosalinella rugosa Marie)

Globotruncana ventricosa White, 1928

Globotruncanella havanensis (Voorwijk, 1937) (= Globotruncana havanensis Voorwijk)

Globotruncanella minuta Caron and Gonzales Donoso, 1984

Globotruncanella petaloidea (Gandolfi, 1955) (= Globotruncana (Rugoglobigerina) petaloidea Gandolfi)

Globotruncanella pschadae (Keller, 1946) (= Globorotalia pschadae Keller)

Globotruncanita angulata (Tilev, 1951) (= Globotruncana lugeoni var. angulata Tilev)

Globotruncanita conica (White, 1928) (= Globotruncana conica White)

Globotruncanita pettersi (Gandolfi, 1955) (= Globotruncana rosetta pettersi Gandolfi)

Globotruncanita stuarti (de Lapparent, 1918) (= Rosalina stuarti de Lapparent)

Globotruncanita stuartiformis (Dalbiez, 1955) (= Globotruncana stuartiformis Dalbiez)

Gublerina acuta de Klasz, 1953

Gublerina cuvillieri Kikoine, 1948

Guembelitria cretacea Cushman, 1933

Hedbergella delrioensis (Carsey, 1926) (= Globigerina cretacea var. delrioensis Carsey)

Hedbergella flandrini Porthault, 1970

Hedbergella holmdelensis Olsson, 1964

Hedbergella monmouthensis (Olsson, 1960) (= Globorotalia monmouthensis Olsson)

Hedbergella planispira (Tappan, 1940) (= Globigerina planispira Tappan)

Helvetoglobotruncana helvetica (Bolli, 1945) (= Globotruncana helvetica Bolli)

Heterohelix carinata (Cushman, 1938) (= Guembelina carinata Cushman)

Heterohelix globulosa (Ehrenberg, 1840) (= Textularia globulosa Ehrenberg)

Hetrohelix labellosa Nederbragt, 1990

Heterohelix moremani (Cushman, 1938) (= Guembelina moremani Cushman)

Heterohelix navarroensis Loeblich, 1951

Heterohelix punctulata (Cushman, 1938) (= Guembelina punctulata Cushman) 
Heterohelix planata (Cushman, 1938) (= Guembelina planata Cushman)

Heterohelix rajagopalani (Govindan, 1972) (= Gublerina rajagopalani Govindan)

Heterohelix reussi (Cushman, 1938) (= Guembelina reussi Cushman)

Heterohelix sphenoides Masters, 1976

Heterohelix striata (Ehrenberg, 1840) (= Textularia striata Ehrenberg)

Kefiana sp.

Kuglerina rotundata (Brönnimann, 1952) (= Rugoglobigerina rugosa rotundata Brönnimann)

Laeviheterohelix dentata Stenestad, 1968

Laeviheterohelix pulchra (Brotzen, 1936) (= Guembelina pulchra Brotzen)

Laeviheterohelix turgida Nederbragt, 1990

Marginotruncana coronata (Bolli, 1945) (= Globotruncana lapparenti subsp. coronata Bolli)

Marginotruncana marginata (Reuss, 1845) (= Rosalina marginata Reuss)

Marginotruncana pseudolinneiana Pessagno, 1967

Marginotruncana renzi (Gandolfi, 1942) (= Globotruncana renzi Gandolfi)

Marginotruncana schneegansi (Sigal, 1952) (= Globotruncana schneegansi Sigal)

Marginotruncana sigali (Reichel, 1950) (= Globotruncana sigali Reichel)

Marginotruncana sinuosa Porthault, 1970

Planoglobulina acervulinoides (Egger, 1899) (= Guembelina acervulinoides Egger)

Planoglobulina carseyae (Plummer, 1931) (= Ventilabrella carseyae Plummer)

Planoglobulina riograndensis (Martin, 1972) (= Ventilabrella riograndensis Martin)

Plummerita hantkeninoides (Brönnimann, 1952) (= Rugoglobigerina hantkeninoides Brönnimann)

Praeglobotruncana gibba Klaus, 1960

Praeglobotruncana stephani (Gandolfi, 1942) (= Globotruncana stephani Gandolfi)

Pseudoguembelina costellifera Masters, 1976
Pseudoguembelina costulata (Cushman, 1938) (= Guembelina costulata Cushman)

Pseudoguembelina excolata (Cushman, 1926) (= Guembelina excolata Cushman)

Pseudoguembelina hariaensis Nederbragt, 1990

Pseudoguembelina kempensis Esker, 1968

Pseudoguembelina palpebra Brönnimann and Brown, 1953

Pseudotextularia elegans (Rzehak, 1891) (= Cuneolina elegans Rzehak)

Pseudotextularia intermedia de Klasz, 1953

Pseudotextularia nuttalli (Voorwijk, 1937) (= Guembelina nuttalli Voorwijk)

Racemiguembelina fructicosa (Egger, 1899) (= Guembelina fructicosa Egger)

Radotruncana calcarata (Cushman, 1927) (= Globotruncana calcarata Cushman)

Rugoglobigerina hexacamerata Brönnimann, 1952

Rugoglobigerina macrocephala Brönnimann, 1952

Rugoglobigerina milamensis Smith and Pessagno, 1973

Rugoglobigerina pennyi Brönnimann, 1952

Rugoglobigerina reicheli Brönnimann, 1952

Rugoglobigerina rugosa (Plummer, 1926) (= Globigerina rugosa Plummer)

Rugotruncana sp.

Sigalia decoratissima carpatica Salaj and Samuel, 1963

Sigalia deflaensis rugocostata Nederbragt, 1990

Ventilabrella eggeri Cushman, 1928

Ventilabrella multicamerata (de Klasz, 1953) (= Planoglobulina multicamerata de Klasz)

Whiteinella aprica (Loeblich and Tappan, 1961) (= Hedbergella aprica Loeblich and Tappan)

Whiteinella archaeocretacea Pessagno, 1967

Whiteinella baltica Douglas and Rankin, 1969

Whiteinella paradubia (Sigal, 1952) (= Globigerina paradubia Sigal)

Whiteinella praehelvetica (Trujillo, 1960) (= Rugoglobigerina praehelvetica Trujillo) 


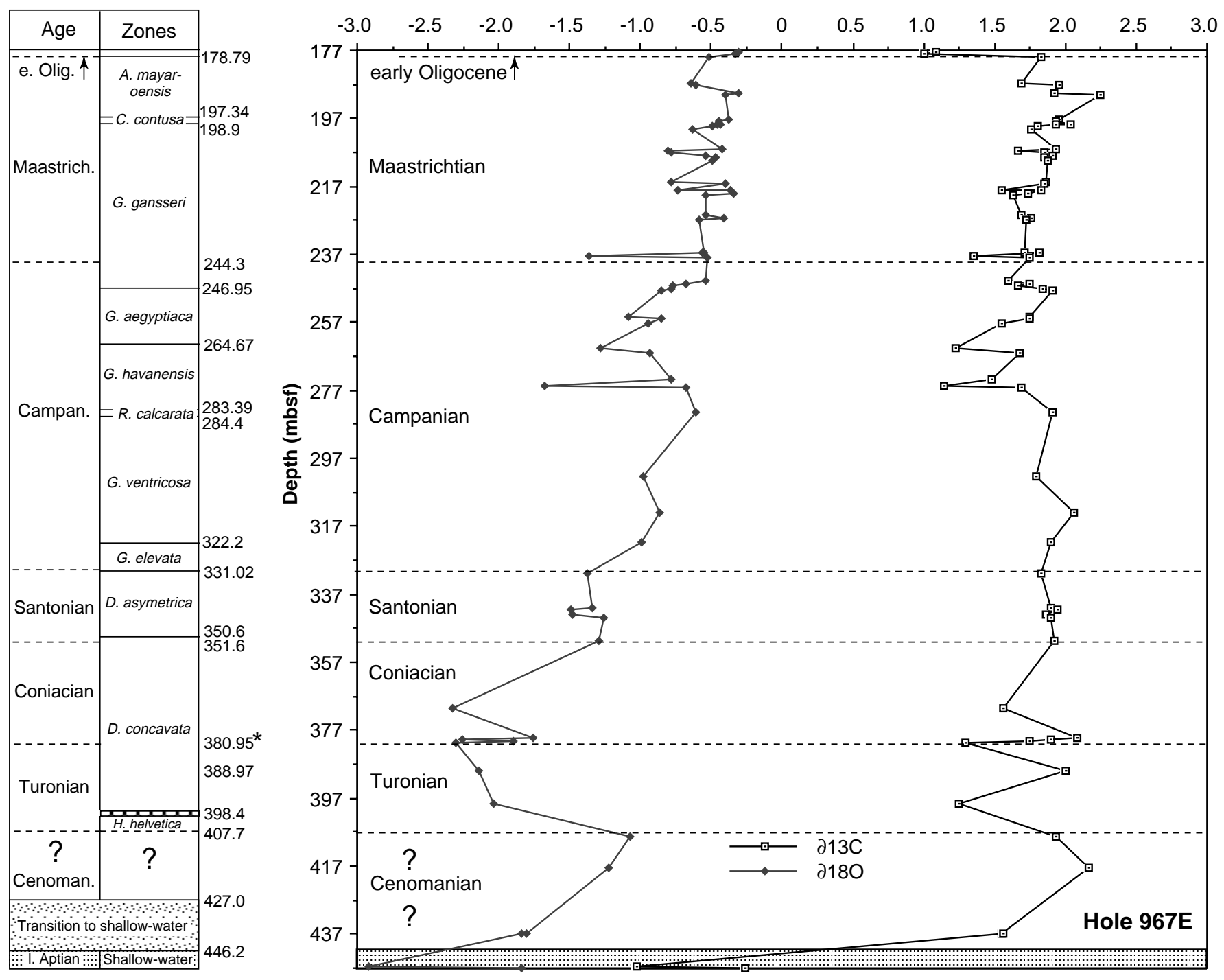

Figure 5. Oxygen and carbon isotope record $\left(\delta^{18} \mathrm{O}\right.$ and $\left.\delta^{13} \mathrm{C}\right)$ of the Cretaceous sequence (Hole 967E) plotted vs. planktonic foraminiferal zones, age, and depth. Note: * at $380.95 \mathrm{mbsf}=$ carbon isotope shift correlated to the Turonian/Coniacian boundary (see text section, "Cretaceous Isotope Stratigraphy," for explanation). 
Table 5. Stable isotopes $\left(\delta^{13} \mathrm{O}\right.$ and $\left.\delta^{13} \mathrm{C}\right)$ of Cretaceous bulk samples from Hole 967E.

\begin{tabular}{|c|c|c|c|}
\hline $\begin{array}{l}\text { Core, section, } \\
\text { interval }(\mathrm{cm})\end{array}$ & Depth & $\delta^{13} \mathrm{C}$ & $\delta^{13} \mathrm{O}$ \\
\hline \multicolumn{4}{|l|}{ 160-967E- } \\
\hline 8R-1, 41-43 & 177.31 & 1.08 & -0.302 \\
\hline $8 \mathrm{R}-1,92-94$ & 177.82 & 1.005 & -0.333 \\
\hline $8 R-2,50-52$ & 178.79 & 1.824 & -0.519 \\
\hline $9 \mathrm{R}-1,3-8$ & 186.53 & 1.69 & -0.639 \\
\hline 9R-1, 51-53 & 187.01 & 1.957 & -0.612 \\
\hline 9R-3, 57-59 & 189.5 & 1.916 & -0.308 \\
\hline 9R-3, 111-114 & 190.04 & 2.243 & -0.403 \\
\hline $10 \mathrm{R}-1,114-117$ & 197.34 & 1.961 & -0.372 \\
\hline $10 \mathrm{R}-2,0-3$ & 197.58 & 1.928 & -0.45 \\
\hline $10 \mathrm{R}-2,98-100$ & 198.56 & 2.038 & -0.438 \\
\hline $10 \mathrm{R}-3,0-4$ & 198.9 & 1.934 & -0.454 \\
\hline $10 \mathrm{R}-3,60-62$ & 199.5 & 1.81 & -0.489 \\
\hline $10 \mathrm{R}-3,127-129$ & 200.17 & 1.761 & -0.628 \\
\hline $11 \mathrm{R}-1,4-6$ & 205.84 & 1.93 & -0.427 \\
\hline $11 \mathrm{R}-1,57-59$ & 206.37 & 1.663 & -0.802 \\
\hline $11 \mathrm{R}-2,38-40$ & 207.21 & 1.855 & -0.788 \\
\hline $11 \mathrm{R}-3,32-38$ & 208.15 & 1.908 & -0.544 \\
\hline $11 \mathrm{R}-3,82-84$ & 208.65 & 1.846 & -0.47 \\
\hline 11R-CC, 33-35 & 209.28 & 1.873 & -0.489 \\
\hline $12 \mathrm{R}-1,12-14$ & 215.52 & 1.861 & -0.788 \\
\hline $12 \mathrm{R}-1,72-74$ & 216.12 & 1.846 & -0.399 \\
\hline $12 \mathrm{R}-2,109-113$ & 217.99 & 1.551 & -0.738 \\
\hline $12 \mathrm{R}-3,0-3$ & 218.16 & 1.828 & -0.368 \\
\hline $12 \mathrm{R}-3,90-93$ & 219.06 & 1.736 & -0.348 \\
\hline $12 \mathrm{R}-4,11-15$ & 219.61 & 1.626 & -0.545 \\
\hline $13 \mathrm{R}-1,42-44$ & 225.52 & 1.693 & -0.541 \\
\hline $13 \mathrm{R}-1,107-108$ & 226.17 & 1.754 & -0.408 \\
\hline $13 \mathrm{R}-2,29-31$ & 226.83 & 1.728 & -0.584 \\
\hline $14 \mathrm{R}-2,26-35$ & 236.46 & 1.717 & -0.552 \\
\hline $14 \mathrm{R}-2,44-47$ & 236.64 & 1.815 & -0.564 \\
\hline $14 \mathrm{R}-2,109-123$ & 237.29 & 1.35 & -1.358 \\
\hline $14 \mathrm{R}-3,13-15$ & 237.83 & 1.749 & -0.523 \\
\hline $15 \mathrm{R}-1,24-26$ & 244.54 & 1.598 & -0.544 \\
\hline $15 \mathrm{R}-1,124-126$ & 245.54 & 1.75 & -0.677 \\
\hline 15R-2, 31-34 & 246.04 & 1.667 & -0.772 \\
\hline $15 \mathrm{R}-2,122-124$ & 246.95 & 1.834 & -0.785 \\
\hline $15 \mathrm{R}-3,20-24$ & 247.43 & 1.908 & -0.853 \\
\hline $16 \mathrm{R}-1,131-140$ & 255.21 & 1.748 & -1.08 \\
\hline $16 \mathrm{R}-2,32-40$ & 255.72 & 1.743 & -0.848 \\
\hline $16 \mathrm{R}-3,35-36$ & 257.2 & 1.545 & -0.949 \\
\hline $17 \mathrm{R}-1,117-120$ & 264.67 & 1.227 & -1.278 \\
\hline $17 \mathrm{R}-2,127-134$ & 266.17 & 1.673 & -0.938 \\
\hline 18R-1, 89-90 & 273.99 & 1.476 & 0.786 \\
\hline $18 \mathrm{R}-2,113-114$ & 275.51 & 1.148 & -1.672 \\
\hline $18 \mathrm{R}-3,29-30$ & 276.09 & 1.693 & -0.681 \\
\hline 19R-1, 69-71 & 283.39 & 1.909 & -0.606 \\
\hline $21 \mathrm{R}-1,46-48$ & 302.36 & 1.792 & -0.982 \\
\hline $21 \mathrm{R}-1,113-116$ & 312.73 & 2.059 & -0.86 \\
\hline $23 \mathrm{R}-2,33-34$ & 321.53 & 1.898 & -0.991 \\
\hline $24 \mathrm{R}-1,22-23$ & 331.02 & 1.828 & -1.374 \\
\hline $25 \mathrm{R}-1,42-43$ & 340.92 & 1.893 & -1.346 \\
\hline $25 \mathrm{R}-1,116-117$ & 341.66 & 1.942 & -1.492 \\
\hline $25 \mathrm{R}-2,93-95$ & 342.89 & 1.865 & -1.483 \\
\hline $25 \mathrm{R}-3,65-67$ & 344.08 & 1.897 & -1.26 \\
\hline $26 \mathrm{R}-1,50-58$ & 350.6 & 1.919 & -1.296 \\
\hline $28 \mathrm{R}-1,107-110$ & 370.37 & 1.562 & -2.328 \\
\hline $29 \mathrm{R}-1,41-48$ & 379.21 & 2.085 & -1.755 \\
\hline $29 \mathrm{R}-1,100-102$ & 379.8 & 1.903 & -2.262 \\
\hline $29 \mathrm{R}-2,10-12$ & 380.4 & 1.749 & -1.896 \\
\hline $29 \mathrm{R}-2,65-67$ & 380.95 & 1.298 & -2.299 \\
\hline $30 \mathrm{R}-1,30-34$ & 388.7 & 2.002 & -2.141 \\
\hline $31 \mathrm{R}-1,4-10$ & 398.44 & 1.246 & -2.04 \\
\hline $32 \mathrm{R}-1,56-60$ & 408.26 & 1.933 & -1.074 \\
\hline $33 \mathrm{R}-1,6-12$ & 417.46 & 2.162 & -1.228 \\
\hline $35 \mathrm{R}-1,0-5$ & 436.6 & 1.561 & -1.838 \\
\hline $36 \mathrm{R}-1,10-16$ & 446.3 & -1.031 & -2.919 \\
\hline
\end{tabular}




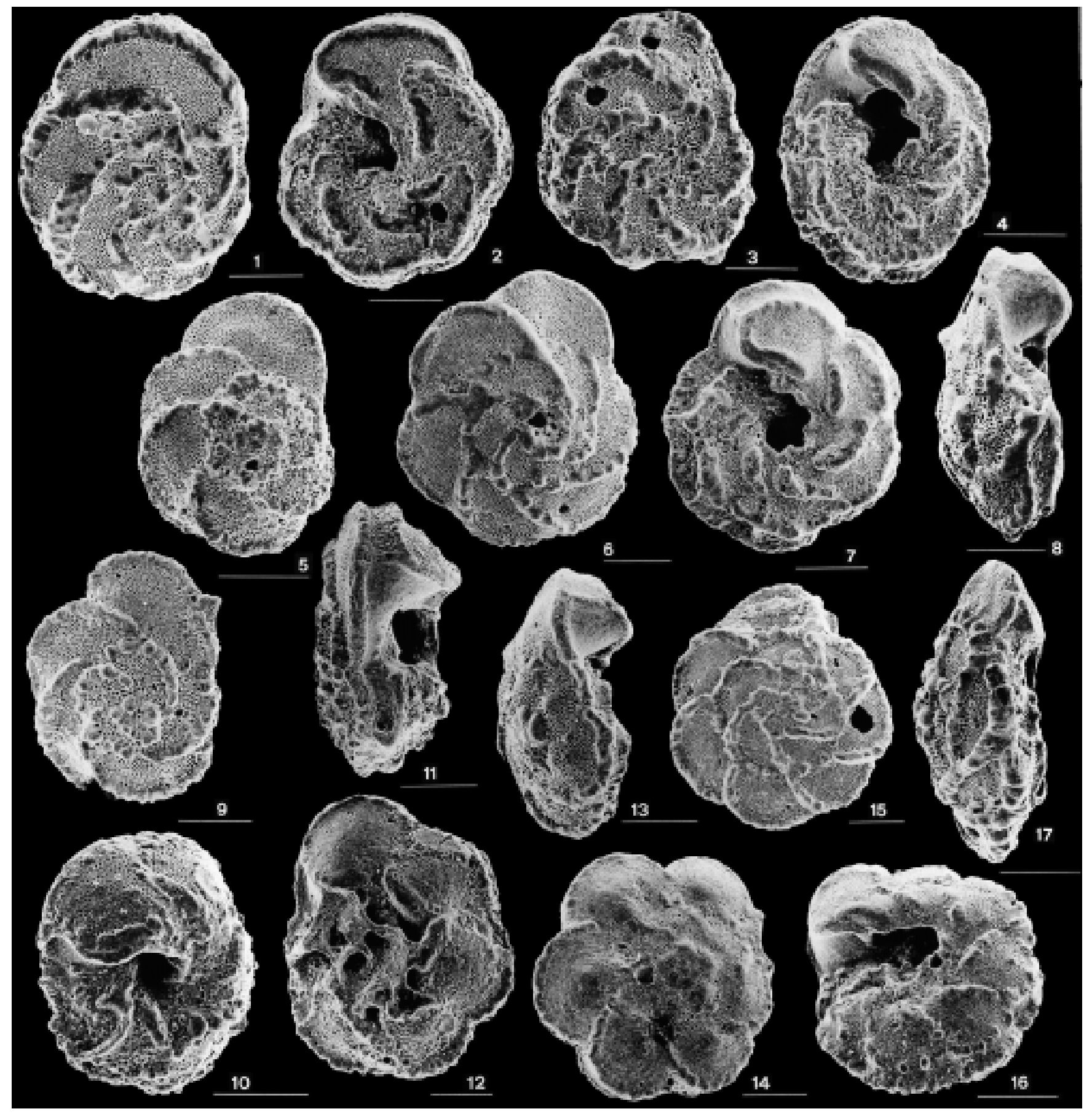

Plate 1. 1. Marginotruncana sinuosa, spiral view. Sample 160-967E-26R-CC. 2. Marginotruncana sinuosa, umbilical view. Sample 160-967E-26R-CC. 3. Marginotruncana coronata, spiral view. Sample 160-967E-27R-CC. 4. Marginotruncana coronata, umbilical view. Sample 160-967E-27R-CC. 5. Marginotruncana pseudolinneiana, spiral view. Sample 160-967E-29R-2, 87-89 cm. 6. Globotruncana arca, spiral view. Sample 160-967E-13R-CC. 7. Globotruncana arca, umbilical view. Sample 160-967E-13R-CC. 8. Globotruncana arca, side view. Sample 160-967E-13R-CC. 9. Globotruncana rosetta, spiral view. Sample 160-967E-10R-CC. 10. Globotruncana rosetta, umbilical view. Sample 160-967E-10R-CC. 11. Globotruncana ventricosa, side view. Sample 160-967E-10RCC. 12. Globotruncana ventricosa, umbilical view. Sample 160-967E-10R-CC. 13. Globotruncana bulloides, side view. Sample 160-967E-13R-CC. 14. Globotruncana bulloides, spiral view. Sample 160-967E-13R-CC. 15. Globotruncana orientalis, spiral view. Sample 160-967E-10R-CC. 16.Globotruncana orientalis, umbilical view. Sample 160-967E-10R-CC. 17. Globotruncana orientalis, side view. Sample 160-967E-10R-CC. All scale bars $=100 \mu \mathrm{m}$. 


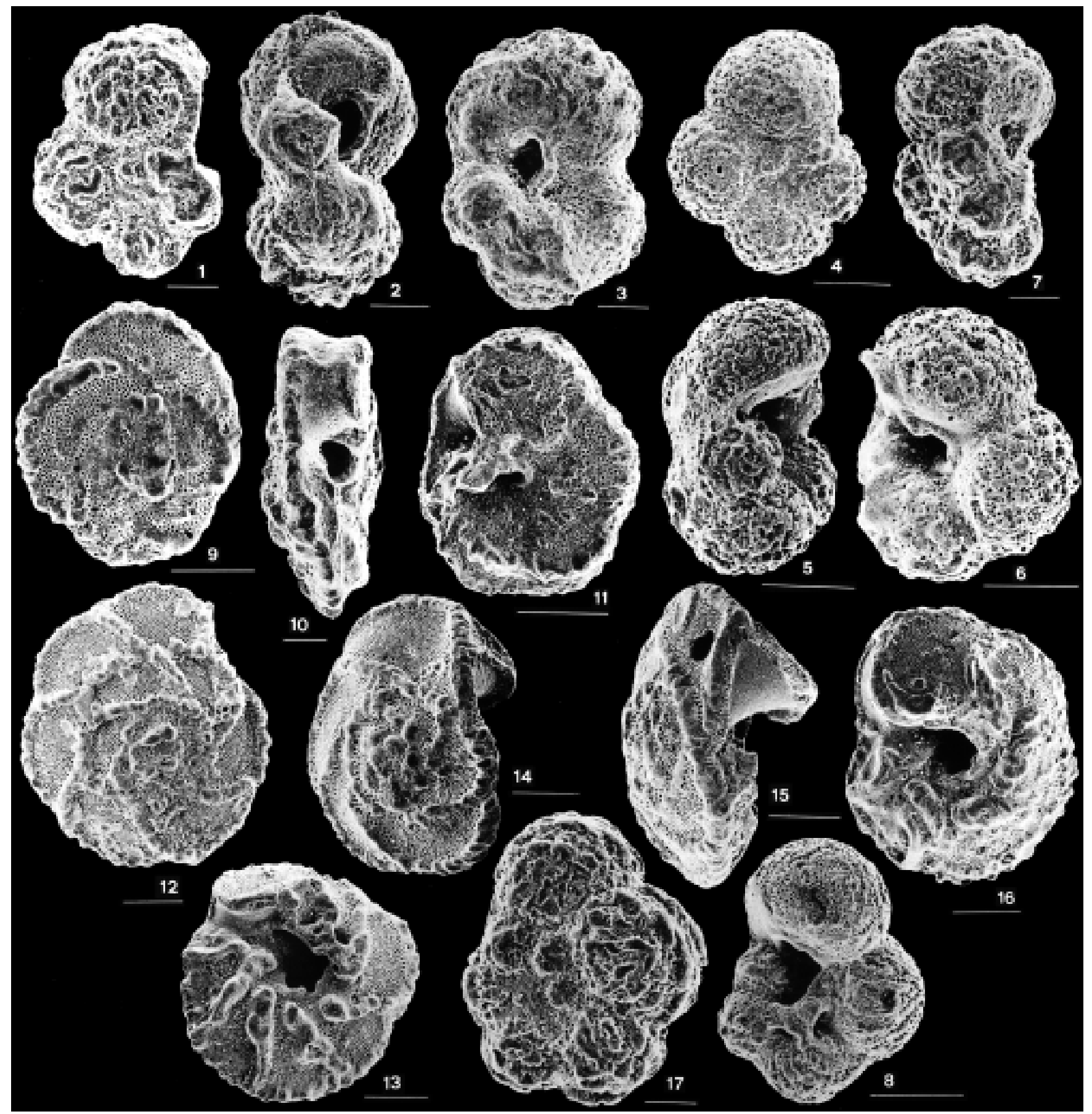

Plate 2. 1. Rugoglobigerina macrocephala, spiral view. Sample 160-967E-13R-CC. Scale bar $=40 \mu \mathrm{m}$. 2. Rugoglobigerina macrocephala, side view. Sample 160-967E-13R-CC. Scale bar $=40 \mu \mathrm{m}$. 3. Rugoglobigerina macrocephala, umbilical view. Sample 160-967E-13R-CC. Scale bar $=40 \mu \mathrm{m} .4$. Archaeoglobigerina blowi, spiral view. Sample 160-967E-8R-CC. Scale bar $=100 \mu \mathrm{m}$. 5. Archaeoglobigerina blowi, side view. Sample 160-967E-8R-CC. Scale bar $=100 \mu \mathrm{m}$. 6. Archaeoglobigerina blowi, umbilical view. Sample 160-967E-8R-CC. Scale bar $=100 \mu \mathrm{m}$. 7. Rugoglobigerina rugosa, side view. Sample 160-967E-13R-CC. Scale bar $=40 \mu \mathrm{m}$. 8. Rugoglobigerina rugosa, umbilical view. Sample 160-967E-8R-CC. Scale bar $=100 \mu \mathrm{m}$. 9. Abathomphalus mayaroensis, spiral view. Sample 160-967E-8R-CC. Scale bar $=100 \mu \mathrm{m}$. 10. Abathomphalus mayaroensis, side view. Sample 160-967E-8R-CC. Scale bar $=40 \mu \mathrm{m}$. 11. Abathomphalus mayaroensis, umbilical view. Sample 160-967E-8R-CC. Scale bar $=100 \mu \mathrm{m}$. 12. Globotruncana dupeublei, spiral view. Sample 160-967E-10R-CC. Scale bar $=$ $100 \mu \mathrm{m}$. 13. Globotruncana dupeublei, umbilical view. Sample 160-967E-10R-CC. Scale bar $=100 \mu \mathrm{m}$. 14. Globotruncanita stuartiformis, spiral view, slightly oblique. Sample 160-967E-10R-CC. Scale bar $=100 \mu \mathrm{m}$. 15. Globotruncanita stuartiformis, side view. Sample 160-967E-10R-CC. Scale bar $=100 \mu \mathrm{m}$. 16. Globotruncanita stuartiformis, umbilical view. Sample 160-967E-10R-CC. Scale bar = $100 \mu \mathrm{m}$. 17. Rugotruncana? sp., spiral view. Sample 160-967E-13R-CC. Scale bar $=40 \mu \mathrm{m}$. 


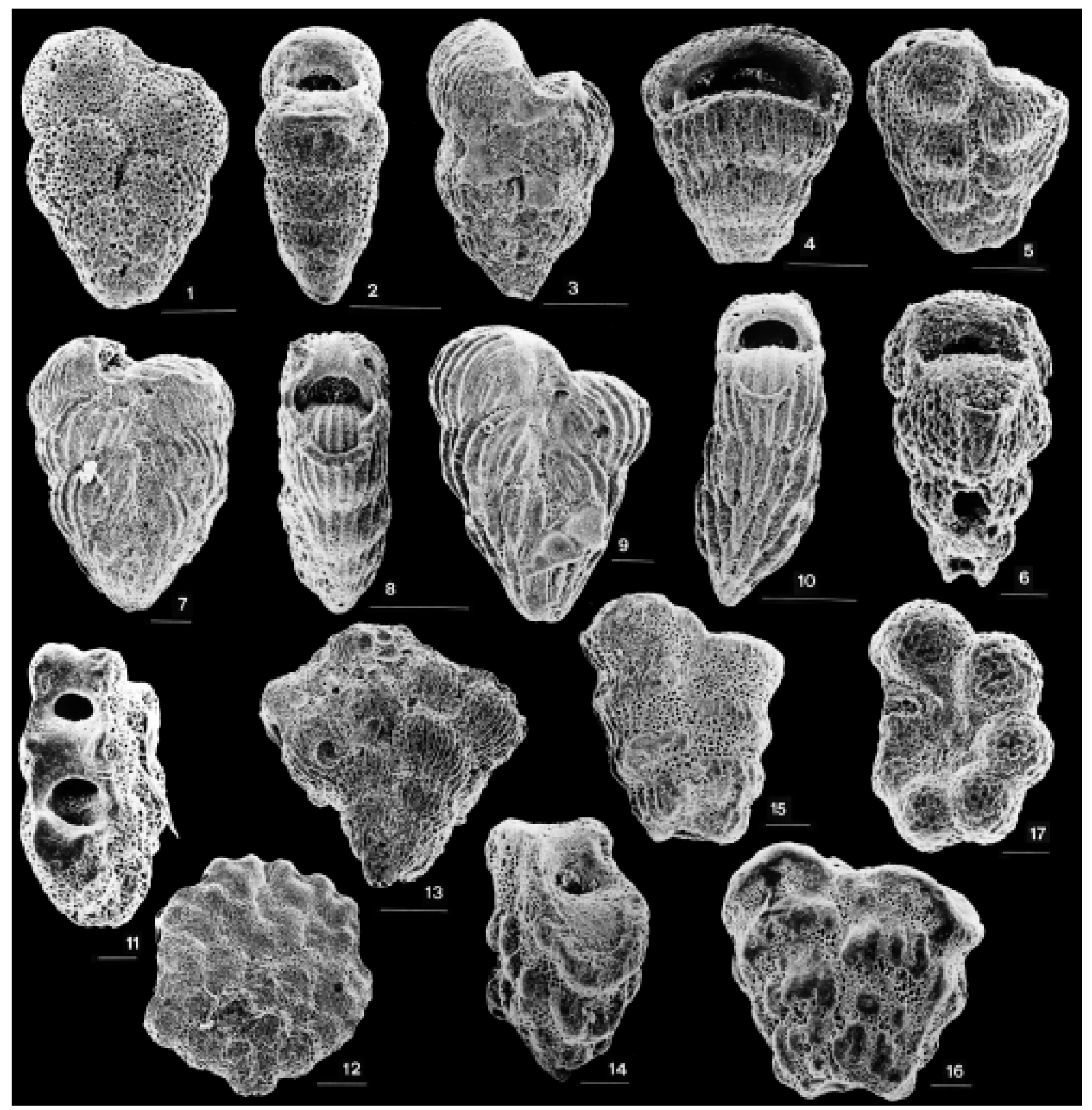

Plate 3. 1. Heterohelix punctulata, side view. Sample 160-967E-10R-CC. Scale bar $=100 \mu \mathrm{m}$. 2. Heterohelix punctulata, edge view. Sample 160-967E-10R-CC. Scale bar $=100 \mu \mathrm{m}$. 3. Pseudo-textularia elegans, side view. Sample 160-967E-8R-CC. Scale bar $=100 \mu \mathrm{m}$. 4. Pseudotextularia elegans, edge view. Sample 160-967E-8R-CC. Scale bar $=100 \mu \mathrm{m}$. 5. Heterohelix carinata, side view. Sample 160-967E-26R-CC. Scale bar $=40 \mu \mathrm{m}$. 6. Heterohelix carinata, edge view. Sample 160-967E-26R-CC. Scale bar $=20 \mu \mathrm{m}$. 7. Pseudoguembelina costulata, side view. Sample 160-967E-8R-CC. Scale bar $=40 \mu \mathrm{m}$. 8. Pseudoguembelina costulata, edge view. Sample 160-967E-8R-CC. Scale bar $=100 \mu \mathrm{m}$. 9. Pseudoguembelina excolata, side view. Sample 160-967E-10R-CC. Scale bar $=40 \mu \mathrm{m}$. 10. Pseudoguembelina excolata, edge view. Sample 160-967E-10R-CC. Scale bar $=100 \mu \mathrm{m}$. 11. Ventilabrella multicamerata, apertural view. Sample 160-967E10R-CC. Scale bar $=40 \mu \mathrm{m}$. 12. Ventilabrella multicamerata, side view. Sample 160-967E-10R-CC. Scale bar $=100 \mu \mathrm{m}$. 13. Planoglobulina acervulinoides, side view. Sample 160-967E-10R-CC. Scale bar $=100 \mu \mathrm{m}$. 14. Sigalia decoratissima carpatica , apertural view. Sample 160-967E-26R-CC. Scale bar $=40 \mu \mathrm{m}$. 15. Sigalia decoratissima carpatica, side view. Sample 160-967E-26R-CC. Scale bar $=40 \mu \mathrm{m}$. 16. Sigalia decoratissima carpatica, side view. Sample 160967E-26R-CC. Scale bar $=40 \mu \mathrm{m}$. 17. Globigerinelloides prairiehillensis, umbilical view. Sample 160-967E-13R-CC. Scale bar $=40 \mu \mathrm{m}$. 


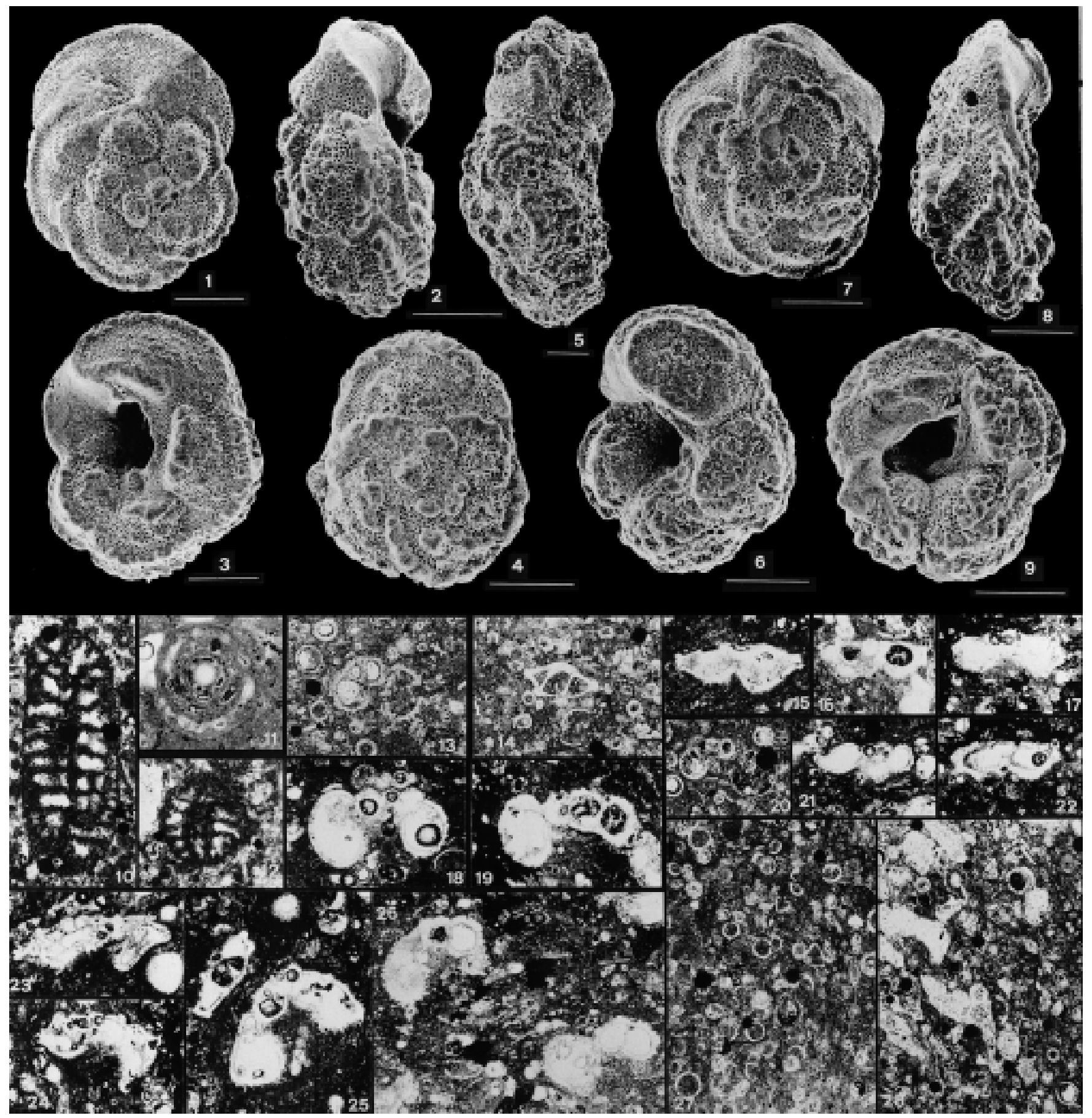

Plate 4. 1. Contusotruncana fornicata, spiral view. Sample 160-967E-10R-CC. Scale bar $=100 \mu \mathrm{m}$. 2. Contusotruncana fornicata, side view. Sample $160-967 \mathrm{E}-$ 10R-CC. Scale bar $=100 \mu \mathrm{m}$. 3. Contusotruncana fornicata, umbilical view. Sample 160-967E-10R-CC. Scale bar $=100 \mu \mathrm{m} .4$. Contusotruncana plummerae, spiral view. Sample 160-967E-19R-1, 69-71 cm. Scale bar $=100 \mu \mathrm{m}$. 5. Contusotruncana plummerae. Scale bar $=40 \mu \mathrm{m}$. 6. Contusotruncana plummerae, umbilical view. Sample 160-967E-10R-CC. Scale bar $=100 \mu \mathrm{m}$. 7. Contusotruncana patelliformis, spiral view. Sample 160-967E-10R-CC. Scale bar $=100 \mu \mathrm{m}$. 8. Contusotruncana patelliformis, side view. Sample 160-967E-10R-CC. Scale bar $=100 \mu \mathrm{m}$. 9. Contusotruncana patelliformis, umbilical view. Sample 160967E-10R-CC. Scale bar $=100 \mu \mathrm{m}$. 10. Cuneolina sp., transversal view. Sample 160-967E-35R-1, $2-5 \mathrm{~cm}, 55 \times$. 11. Archaealveolina reicheli, equatorial view. Sample 160-967E-41R-1, 2-5 cm, 80×. 12. Archaealveolina reicheli, tangential view. Sample 160-967E-41R-1, 2-5 cm, 55×. 13. Favusella washitensis, axial view. Sample 160-967E-32R-1, 56-60 cm, 55×. 14. Rotalipora sp., not centered axial view. Sample 160-967E-33R-1, 7-10 cm, 55×. 15. Dicarinella primitiva, axial view. Sample 160-967E-30R-1, 15-20 cm, 55×. 16. Dicarinella primitiva, axial view. Sample 160-967E-30R-1, 30-34 cm, 55×. 17. Dicarinella sp., axial view. Sample 160-967E-30R-1, 30-34 cm, 55×. 18. Whiteinella baltica, axial view. Sample 160-967E-30R-1, 15-20 cm, 55×. 19. Whiteinella aprica, axial view. Sample 160-967E-30R-1, 30-34 cm, 55×. 20. Hedbergella delrioensis, axial view. Sample 160-967E-32R-1, 56-60 cm, 55×. 21. Hedbergella flandrini, axial view. Sample 160-967E-30R-1, 30-34 cm, 55×. 22. Dicarinella? sp., axial view. Sample 160-967E-30R-1, 30-34 cm, 55×. 23. Marginotruncana sigali group, axial view. Sample 160-967E-30R-1, 15-20 cm, 55×. 24. Marginotruncana sp. aff. M. marianosi, axial view. Sample 160-967E-30R-1, 30-34 cm, 55×. 25. Praeglobotruncana gibba (right) and Dicarinella canaliculata (above left), both axial views. Sample 160-967E-30R-1, 15-20 cm, 55×. 26. Two specimens of Whiteinella sp., oblique views. Sample 160-967E-30R-1, 30-34 cm, 55×. 27. Calcispheres. Sample 160-967E-33R-1, 7-10 cm, 60×. 28. Calcispheres and echinoid fragments. Sample 160-967E-32R-1, 12-14 cm, 60X. 